\title{
14. DEEP-WATER TRACE FOSSILS AND THEIR ENVIRONMENTAL SIGNIFICANCE IN FOREARC AND BACKARC CENOZOIC SUCCESSIONS AROUND THE IZU-BONIN ARC, LEG $\mathbf{1 2 6}^{1}$
}

\author{
A. Colella, ${ }^{2}$ A. D'Alessandro, ${ }^{3}$ and R. De Rosa ${ }^{2}$
}

\begin{abstract}
Trace fossil assemblages at Sites 788, 790/791, and 792 of Ocean Drilling Program Leg 126 were examined to improve understanding of the depositional processes in the area of the intraoceanic Izu-Bonin Arc. In the backarc area, analyses of biogenic structures indicate that most of the muddy sediments filling the backarc basin were emplaced by sediment gravity flows from the surrounding highs. Trace fossil assemblages at Site 788, on the eastern margin of the backarc basin, support the hypothesis that in the interval from 4.1 to $3.8 \mathrm{Ma}$ this site was already a bathymetric high characterized by weak bottom currents. At Site 792 in the forearc basin, biogenic analyses, together with preliminary petrographic and morphoscopic studies of some samples of volcanic grains, indicate that the massive and poorly sorted muddy sandstones and sandy mudstones of Miocene Unit II were mainly emplaced by fallout of both hemipelagic mud and sand-sized pyroclastic grains supplied to the sea by the volcanic fall of pyroclastic material from subaerial volcanoes. This study provides the first description of trace fossils in deep-sea settings dominated by volcaniclastic sedimentation.
\end{abstract}

\section{INTRODUCTION}

The Izu-Bonin region is an intraoceanic arc-trench system (Fig. 1) that has resulted from the subduction of Pacific lithosphere since the Eocene. Ocean Drilling Program (ODP) Leg 126 focused on some poorly understood aspects of the system, such as the origin, evolution, processes, and products of the backarc and the forearc. This study, based on ichnological and sedimentological observations on drilled deep-sea volcaniclastic sediments, contributes to understanding the sedimentation style in the backarc and forearc area as well as the interaction between vertical tectonics and rift sedimentation.

Sediments drilled at Sites 790/791 in the Sumisu backarc rift, at Site 788 in the eastern footwall uplift of the rift, and at Site 792 in the forearc basin (Fig. 2) comprise a wide variety of sedimentary facies and contain well-preserved trace fossil assemblages.

Trace fossils, as is well known, are evidence of the activities (feeding, crawling, dwelling, etc.) of ancient benthic organisms. They can provide valuable information on the main factors acting in the ancient depositional environments, such as sedimentation rate, hydraulic regime, original character of the sediment, amount and temporal variation of oxygen content, salinity, paleobathymetry, and $\mathrm{pH}$ (e.g., Howard, 1978; Frey and Seilacher, 1980; Bromley and Ekdale, 1984; Ekdale et al., 1984; Savrda and Bottjer, 1989).

The purpose of this paper is to describe, for the first time, trace fossil assemblages in deep-sea depositional settings dominated by volcaniclastic sedimentation, and to discuss the environmental implications of the preserved ichnofabrics in Leg 126 sediments for a better understanding of the depositional processes in the Izu-Bonin region. In particular this paper focuses on

1. the depositional processes of the massive, thick, muddy intervals that represent most of the infill of the backarc basin;

2. recognition of the distinctive trace fossil assemblages in the backarc and forearc deposits that resulted from different environmental conditions in the two basins;

${ }^{1}$ Taylor, B., Fujioka, K., et al., 1992. Proc. ODP, Sci. Results, 126: College Station, TX (Ocean Drilling Program).

${ }^{2}$ Dipartimento di Scienze della Terra, Università della Calabria, Cosenza, Italy.

${ }^{3}$ Dipartimento di Geologia e Geofisica, Università di Bari, Bari, Italy.
3. the depositional processes of the massive and poorly sorted deposits of Miocene Unit II at Site 792 in the forearc basin, based partly on preliminary observations on the morphoscopic characteristics of individual volcanogenic grains; and

4. the depositional setting of the eastern footwall uplift of the backarc Sumisu Rift during the Pliocene.

\section{METHODS}

Sedimentary and biogenic structures were observed by means of visual macroscopic observations on wet, split cores. Because trace fossils were viewed on a flat, cut surface, they were only identified at the ichnogenus level. Some traces could not be identified at even the ichnogenus level because of the lack of three-dimensional information. Some X-radiographs were taken in apparently unbioturbated massive horizons to detect biogenic structures.

Three samples selected from Site 792 were laboratory processed to determine the composition and morphology of the grains. Each sample was sieved and the sand fraction was split into two portions: one for stereomicroscopic selection of grains for scanning electron microscope (SEM) investigations, and the other for impregnation with epoxy resin to obtain a thin section for petrographic analysis.

All observations are keyed to facies present in each lithologic unit at Sites 788, 790, 791, and 792. The units (and subunits) were defined in Taylor, Fujioka, et al. (1990). Descriptions of the facies recognized in this paper are based on shipboard data (Taylor, Fujioka, et al., 1990). Each facies is identified by a code that consists of the site number, the unit number, and a subscript uppercase letter (e.g., $790 \mathrm{I}_{\mathrm{A}}$ ). For the subfacies, a subscript uppercase letter and arabic numeral (e.g., $790 \mathrm{I}_{\mathrm{A} 1}$ ) are used.

\section{BACKARC BASIN—SITE 790}

Site 790 is in the western side of the Izu-Bonin Arc, on a slight rise and structural high to the west of the flat basin floor of the eastern half-graben of the Sumisu Rift (Figs. 2 and 3). The Pleistocene sedimentary sequence is $266.6 \mathrm{~m}$ thick and lies on scoriaceous basalt (Fig. 3). The sedimentation rate is high and has been characterized by a strong increase from $80 \mathrm{~m} / \mathrm{m}$.y. at 1 Ma to $1000 \mathrm{~m} / \mathrm{m}$.y. since $0.1 \mathrm{Ma}$. The succession consists of two stratigraphic units composed predominantly of volcanogenic material. 


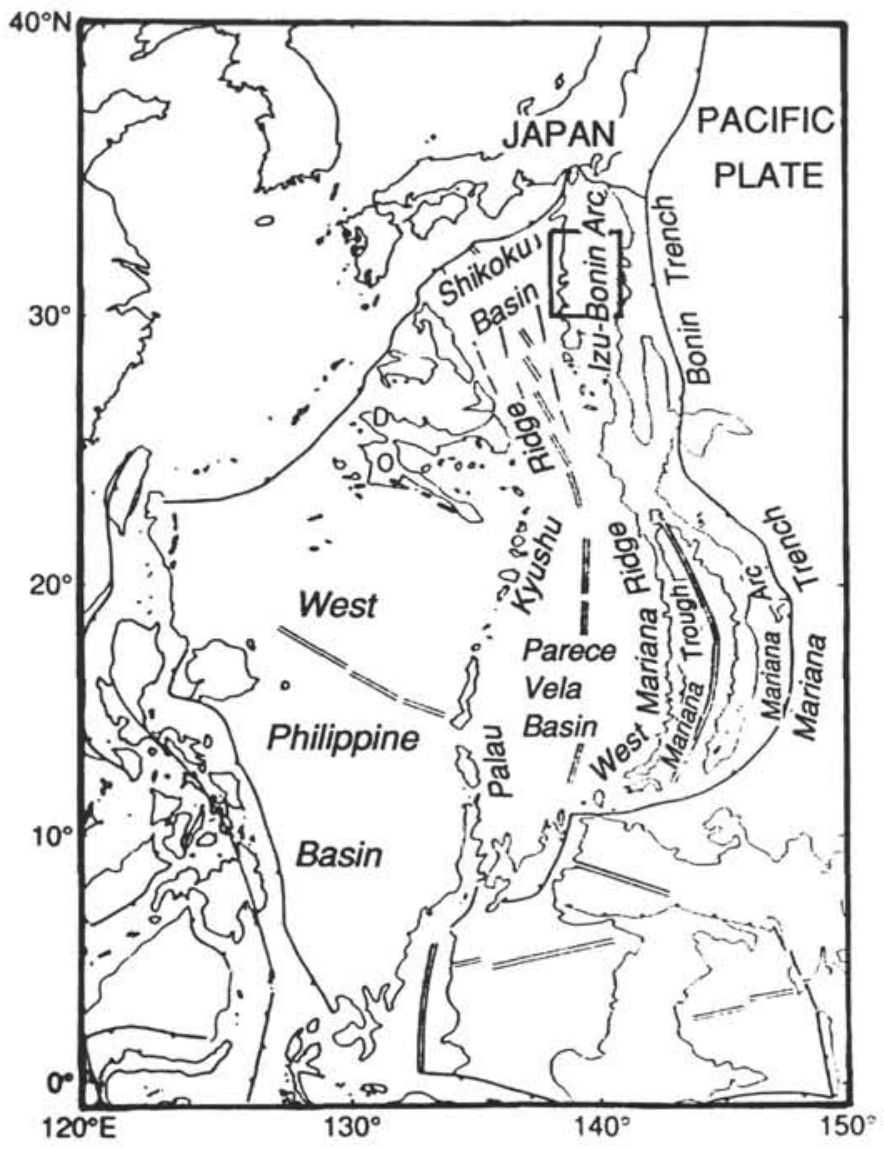

Figure 1. Location of the Izu-Bonin region.

\section{Unit I}

\section{Description}

Unit I (0-165 mbsf; early Pleistocene) consists of a large-scale alternation of four sedimentary facies.

\section{Facies $790 I_{A}$}

This facies consists of structureless or normally graded beds, up to $15 \mathrm{~m}$ thick, of pumiceous gravel, pebbly sand, and vitric silt. The gravel is poorly sorted, with an abundant sand- to silt-sized matrix.

\section{Facies $790 I_{B}$}

Facies $790 \mathrm{I}_{\mathrm{B}}$ consists of thin- to thick-graded beds of sand and silt passing upward with a gradual or sharp contact to mud. Sands are black because of a predominance of brown glass, scoria, and dark mineral grains. The sandy and silty intervals of the beds appear commonly massive or parallel laminated.

Facies $790 I_{C}$

Facies $790 \mathrm{I}_{\mathrm{C}}$ is made up of graded muddy intervals that contain scattered sand- to pebble-sized clasts of pumice and scoria. These horizons commonly pass downward to silty and sandy intervals.

\section{Facies $790 I_{D}$}

Very thin to thin beds of white or dusky green ash are scattered in the graded mud of Facies $790 \mathrm{I}_{\mathrm{D}}$. The beds, which have a sharp or locally erosional basal contact, appear structureless or parallel laminated.

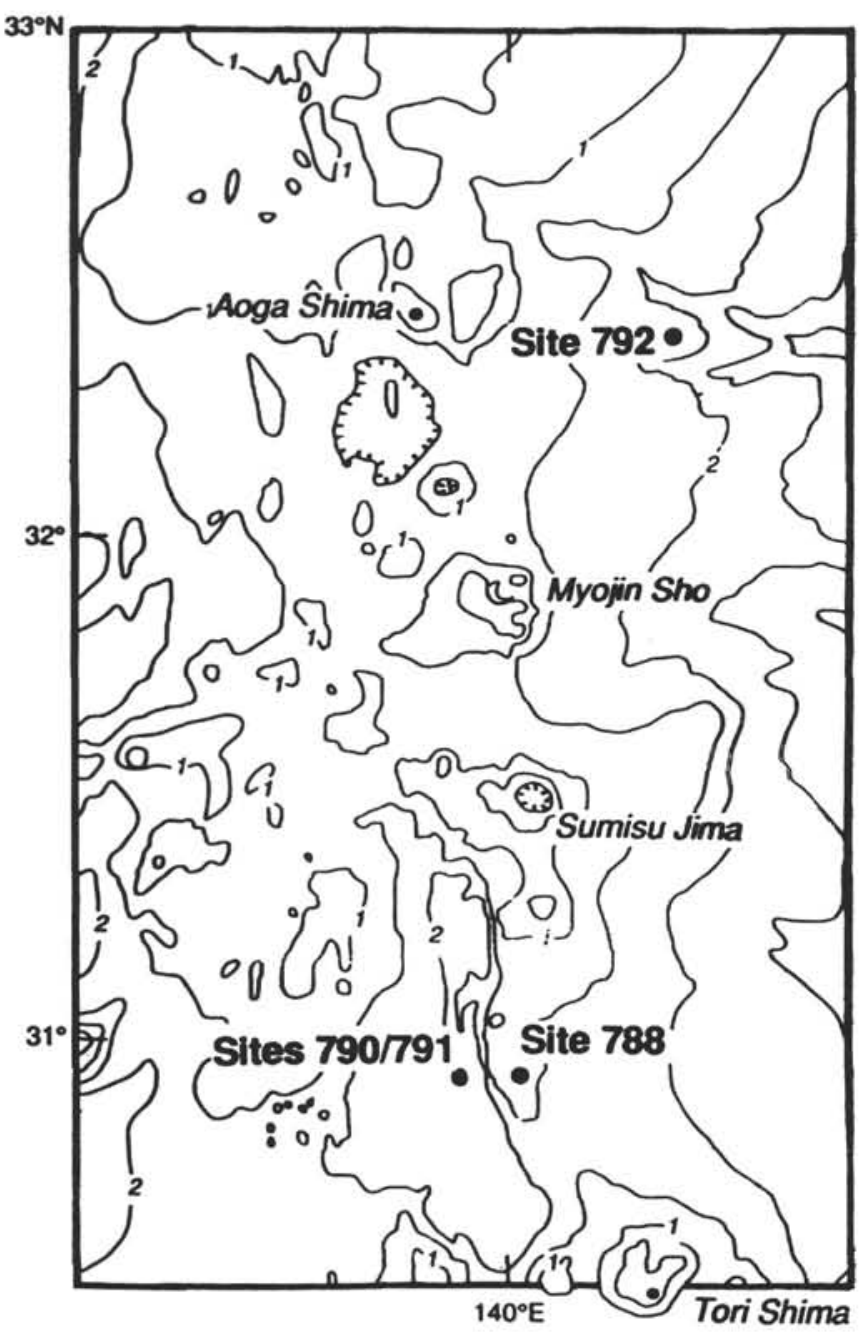

Figure 2. Locations of Sites 788, 790/791, and 792.

\section{Trace Fossil Assemblages}

Facies $790 I_{A}, 790 I_{B}$, and $790 I_{D}$

Trace fossils are absent.

\section{Facies $790 I_{C}$}

In the muddy horizons of Facies $790 \mathrm{I}_{\mathrm{C}}$, trace fossil assemblages are scarce and comprise only two commonly recurring ichnogenera, represented by scattered Planolites and Chondrites, accompanied by tiny Helminthopsis. Locally, Planolites can be found associated with postdating Helminthopsis or Chondrites in a distinctive way: Helminthopsis externally wraps Planolites, whereas Chondrites is nestled in the fill and forms composite burrows. In these cases, Planolites is sharply defined, but generally it is preserved as extremely smeared, indistinct at the boundary of galleries, reflecting compaction of an originally soupy sediment. Low-density and diversity (1 or 2) Planolites- and/or Chondrites-dominated ichnofacies are characteristic, but a monotypic Chondrites suite is not uncommon. Only one light-colored spreite of Zoophycos (3 mm thick) was found in a dark sediment, possibly related to an overlying horizon of small Chondrites.

The trace fossils are mainly restricted to horizons a few centimeters thick in the upper part of the muddy intervals of the graded beds. Characteristically, the intensity of burrowing decreases downward 

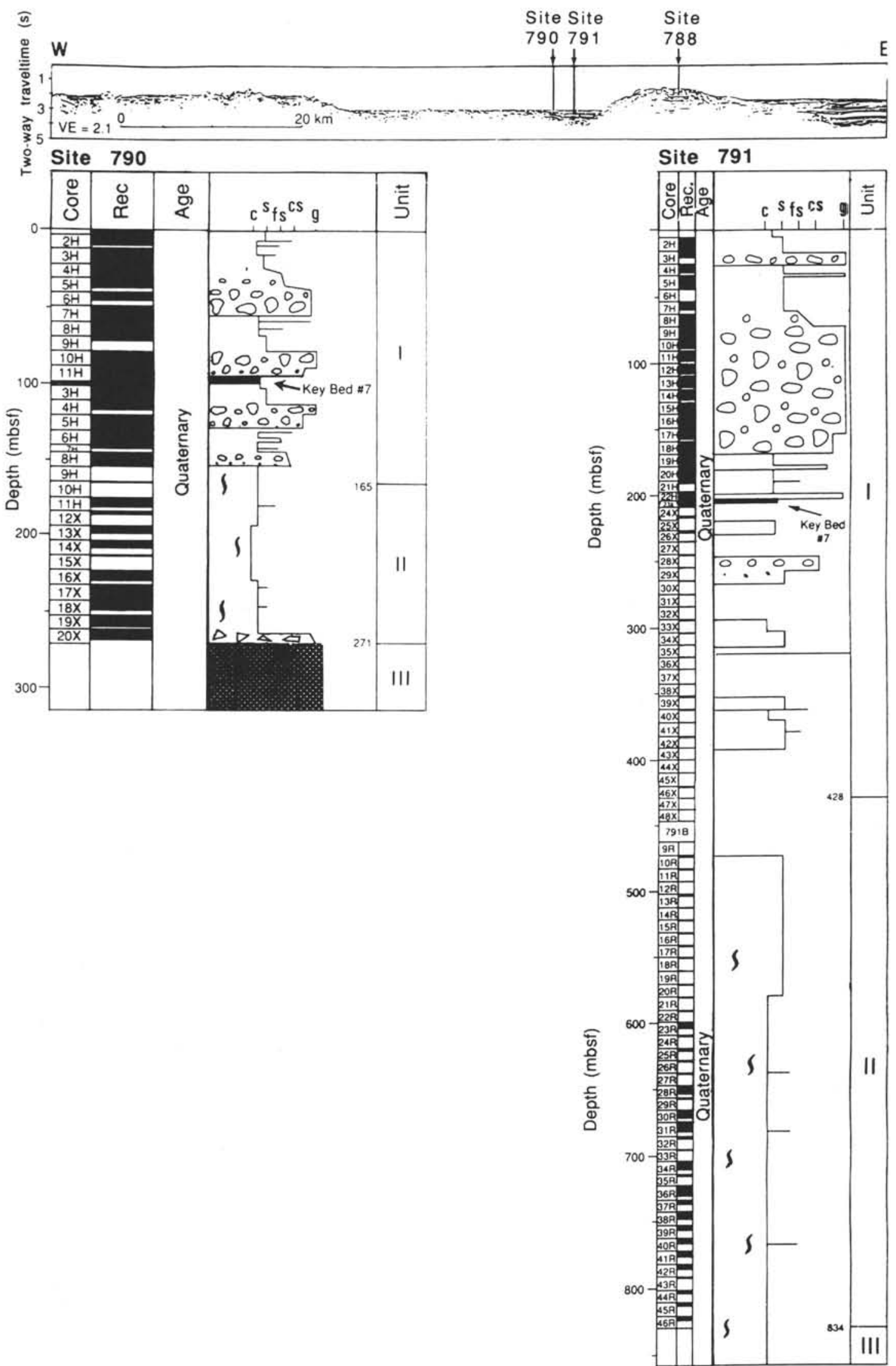

Figure 3. Line drawing of MCS Line BON II-4 (Fred Moore 35-07) showing the location of Sites 790, 791, and 788 (at the top of the figure). Also shown are composite stratigraphic sections for Sites 790 and 791, and unit boundaries. 
(indexes 3 to 2, sensu Droser and Bottjer, 1989); biodeformational structures can be present too. X-ray analyses confirm the visual observation that the bulk of the muddy thick intervals with scattered ash is unbioturbated and structureless. In a few thin to medium beds, bioturbation occurs throughout all the thicknesses, and density can be fairly high (indexes 5 to 4 ) (Fig. 4).

\section{Interpretation}

Facies $790 I_{A}$ and $790 I_{B}$

The absence of trace fossils in the deposits of Facies $790 \mathrm{I}_{\mathrm{A}}$ and $790 I_{B}$ is justified by several factors that can interact with each other. The most important are (1) the coarse grain size of the sediment; (2) the fact that these deposits were emplaced by sediment gravity flows, probably deriving from the surrounding highs (Taylor, Fujioka, et al., 1990); (3) the high depositional rates (up to $1000 \mathrm{~m} / \mathrm{m} . \mathrm{y}$.); and (4) the paucity of nutrients within the deposits, related to the volcaniclastic nature of the clasts and to their high rate of supply that would have diluted any pelagic input.

\section{Facies $790 I_{C}$}

Except under unusual conditions (e.g., anoxic environment, turbidite deposition, etc.), bioturbation rates exceed pelagic sedimentation rates. Therefore, the deep-sea, fine-grained sediments originally possess fabrics induced by benthic, mainly infaunal organisms. Preservational factors can obliterate the ichnofabrics and confer a massive appearance to the sediments, but the same result can derive from a complete biogenic reworking of the substrate. Many of the thick muddy intervals of this facies are apparently structureless; however, in lithologically similar intervals, biodeformational structures are still identifiable by subtle color differences. This observation makes us reasonably certain that, in the structureless muddy intervals interpreted as unbioturbated, the lack of biogenic structures was primary. This can be the result of catastrophic sedimentation from fine-grained density currents or of fallout under anoxic conditions, the latter inhibitive for the development of benthic organisms. The second hypothesis can be reasonably rejected mainly because benthic foraminifers indicate a certain availability of oxygen in the bottom water (low to medium), which would have favored the colonization of the seafloor by Chondrites-maker or similar organisms (Bromley and Ekdale, 1984); the latter, however, are not present in the deposits studied. Furthermore, the first hypothesis is consistent with the high value of sedimentation rates for this unit (Taylor, Fujioka, et al., 1990).

In the scarce and thin bioturbated muddy intervals, the pattern of density variation, as well as the vertical distribution of trace fossils, are indicative of abrupt changes in the rate of sedimentation, typical of environments dominated by turbidite sedimentation. The organisms were able to colonize the sea bottom at the end of mass-flow events during periods of fallout deposition of ash and clay. The low intensity of burrowing can be related to the low concentration of organic matter in this mixed sediment, inadequate to support a large benthic community. The few highly bioturbated ichnofabrics must record periods of omission or very low aggradation of the bottom. The small sizes of the trace fossils and the low diversity of the assemblages, frequently monotypic, suggest prevalently dysaerobic conditions in the interstitial water.

\section{Facies $790 I_{D}$}

Beds of this facies occur scattered in the deposits of both the backarc and forearc basin. A preliminary morphoscopic analysis has been made on one representative sample from Site 792 (see "Petrography and Morphoscopy" section, Facies $792 \mathrm{II}_{\mathrm{C}}$ ). The interpretation is the same as for Facies $792 \mathrm{II}_{\mathrm{C}}$.

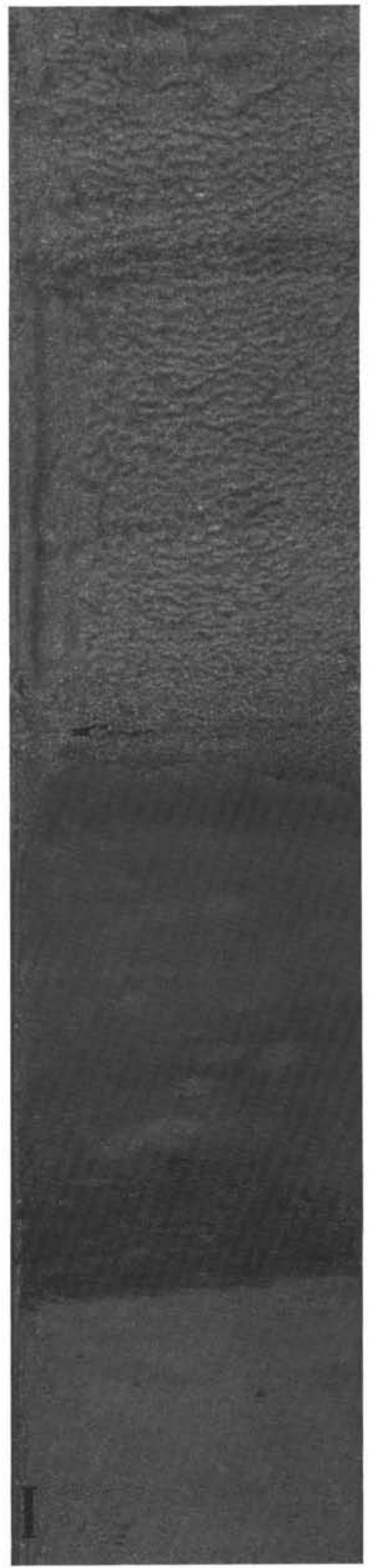

Figure 4. Core photograph, Site 790, Facies $790 \mathrm{I}_{\mathrm{B}}$. Planolites and small Chondrites in a relatively highly bioturbated silty-clay horizon (Key Bed 7) underlying unbioturbated fine sand (ash). A few smeared small-sized Planolites and Chondrites occur in the lower mixed silty clay bed. Sample $126-790 \mathrm{~B}-10 \mathrm{H}-5,1-30 \mathrm{~cm}$. Scale bar $=1 \mathrm{~cm}$. 


\section{Unit II}

\section{Description}

Unit II (165-271 mbsf; early Pleistocene) is a fine-grained succession of two sedimentary facies.

\section{Facies $790 \mathrm{II}_{\mathrm{A}}$}

Facies $790 \mathrm{II}_{\mathrm{A}}$ is composed of medium to very thick graded beds of nannofossil-rich clay and mud with scattered felsic pumice and basaltic clasts, and locally with lower thin divisions of dark sand and silt. The bulk of the sediment is not bioturbated (Fig. 5). There is a general downward increase in the thickness of the beds and in the abundance and size of the felsic and basaltic clasts.

\section{Facies $790 \mathrm{II}_{B}$}

Facies $790 \mathrm{II}_{\mathrm{B}}$ is made up of very thin to thin, sharp-based or erosional beds of grayish green to white ash (Fig. 6), scattered in the other sediments and similar to the beds of Facies $790 \mathrm{I}_{\mathrm{D}}$.

\section{Trace Fossil Assemblages}

\section{Facies $790 \mathrm{II}_{\mathrm{A}}$}

In the scarce bioturbated intervals of Facies $790 \mathrm{II}_{\mathrm{A}}$, the trace fossils are represented by the same ichnogenera as in Unit I, but the absolute and relative abundances are different. Chondrites forms either a monotypic suite or a more diversified assemblage with Planolites and, locally, different-sized Zoophycos. Composite burrows are comparatively common, whereas Helminthopsis has not been identified. The biogenic reworking is somewhat more intense than in Unit I and, furthermore, increases downcore, so that totally bioturbated horizons a few centimeters thick occur in Cores 126$790 \mathrm{C}-16 \mathrm{X},-18 \mathrm{X}$, and $-19 \mathrm{X}$. In the same cores, the diversity is also higher because the trace fossil assemblage is composed of the combined ichnogenera, represented by different-sized burrows.

The clayey and muddy intervals contain biogenic structures with density values that generally range from 2 to 3-4 upward, rarely more (Fig. 7). The trace fossils are restricted to the topmost part of the unbioturbated beds or are regularly scattered throughout their thickness $(20-30 \mathrm{~cm}$ up to $80 \mathrm{~cm})$. In a few thick muddy beds, the vertical repetition of the first pattern, or alternations of the two patterns, can be indicative of amalgamated horizons. In the upper part of Unit II, the burrow distribution suggests local preservation of frozen tiers composed of the low tier Planolites, smeared galleries, the deeper emplaced Chondrites systems, and, exceptionally, Zoophycos. Downcore, the top of the intervals can be indistinctly mottled with vaguely delimited Planolites overprinted by slightly compacted Chondrites, which are themselves cut by other sharply defined Planolites, composite burrows, and small Chondrites (Fig. 7).

\section{Facies $790 I_{B}$}

Secondary burrows are locally present in the topmost part of the otherwise unbioturbated beds of Facies $790 \mathrm{II}_{\mathrm{B}}$.

\section{Interpretation}

Facies $790 \mathrm{II}_{\mathrm{A}}$

The bulk of the sediment of Facies $790 \mathrm{II}_{\mathrm{A}}$ is unbioturbated because it was emplaced by sediment gravity flows. The intensity of reworking is higher than in Unit $\mathrm{I}$, in agreement with the lower $(90$ $\mathrm{m} / \mathrm{m}$.y.) accumulation rates for this basal unit. The rare mottled or highly bioturbated horizons can be interpreted as the record of periods of hemipelagic deposition that appear to increase downcore.

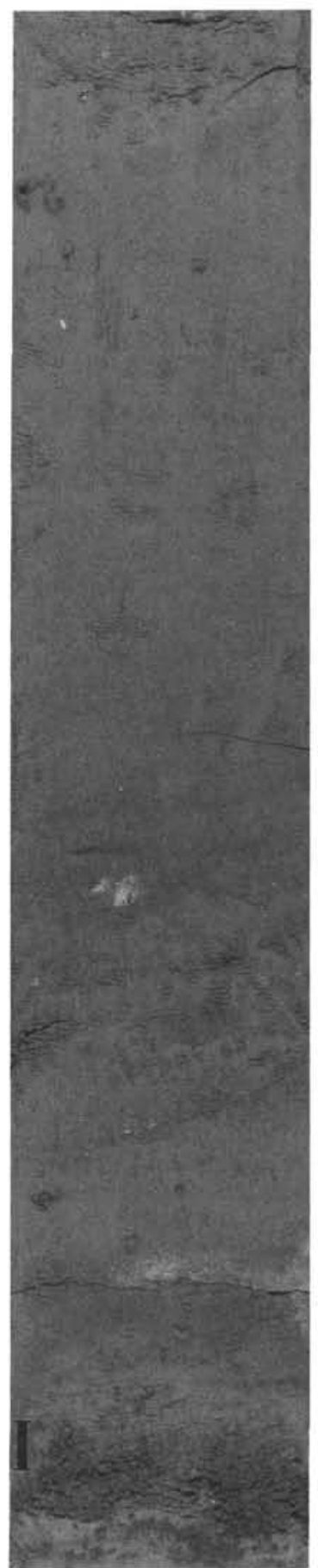

Figure 5. Core photograph, Site 790, Facies $790 \mathrm{II}_{\mathrm{A}}$. Unbioturbated vitric clayey silty and silty bed. Sample $126-790 \mathrm{C}-17 \mathrm{X}, \mathrm{CC}, 2-34 \mathrm{~cm}$. Scale bar $=1 \mathrm{~cm}$.

\section{Chondrites}

Dominant and monotypic Chondrites suites reflect generally oxygen-depleted conditions. Improved conditions, possibly related to an adequate supply of oxygen in the bottom water, are suggested by higher diversity suites in some horizons of Cores 126-790C-16X and mainly $-18 \mathrm{X}$ and $-19 \mathrm{X}$. The frozen tiers, rather than being related to oxygen fluctuations, were probably controlled by the temporal length of hemipelagic sedimentation between successive turbidite currents. 


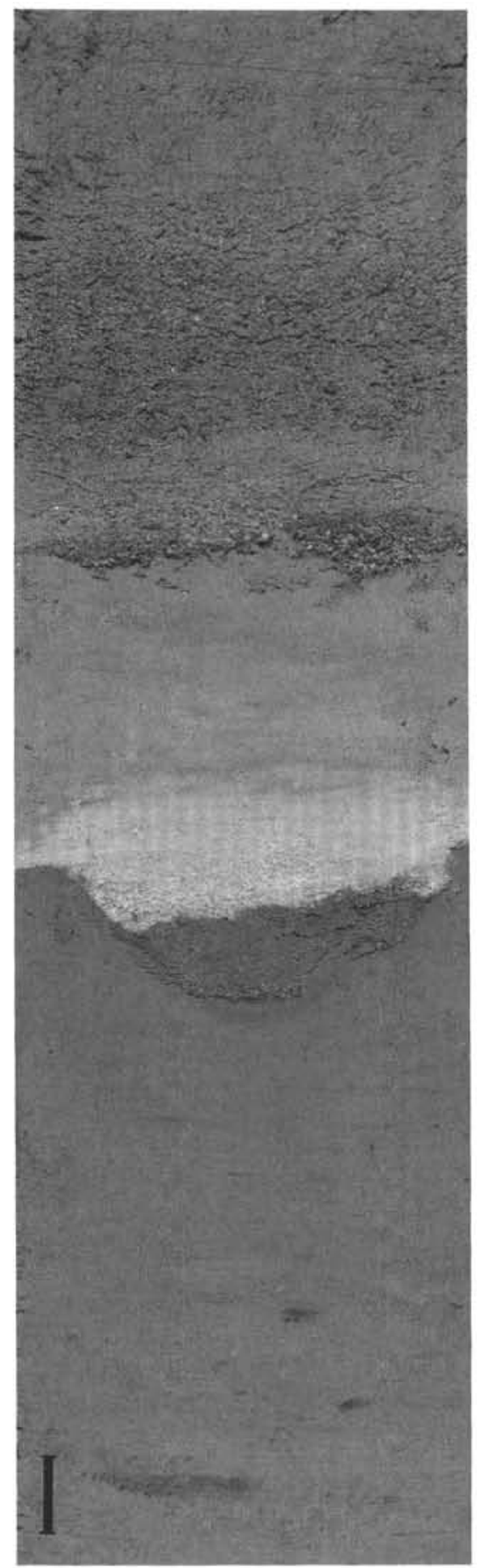

Figure 6. Core photograph, Site 790, Facies $790 \mathrm{II}_{\mathrm{B}}$. From bottom to top: clayey silt with scattered scoria and a few smeared Chondrites; erosional thin bed of dark vitric sand overlaid by white sand and silt grading into clayey silt containing smeared Chondrites; unbioturbated crystal vitric sand. Sample 126$790 \mathrm{C}-11 \mathrm{X}-5,1-21 \mathrm{~cm}$. Scale bar $=1 \mathrm{~cm}$.

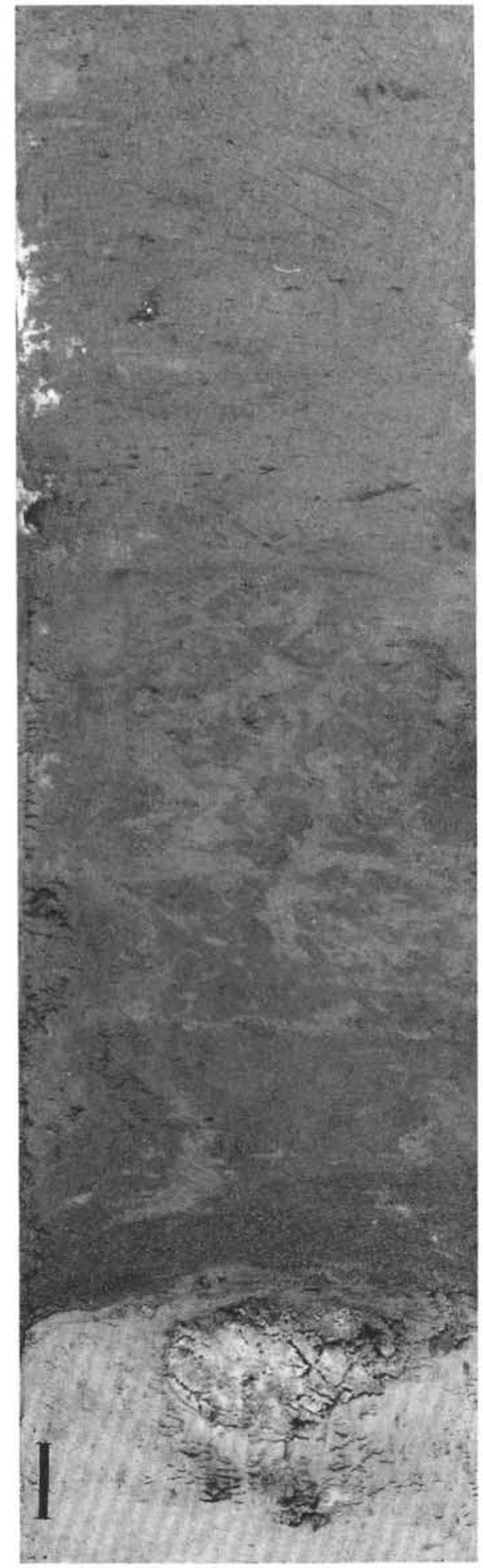

Figure 7. Core photograph, Site 790, Facies $790 \mathrm{II}_{\mathrm{A}}$. One-cm-thick vitric fine sand grades upward into burrowed clayey silt. The number density of trace fossils increases upward where Chondrites and composite burrows are overprinted on an indistinctly burrowed background. The overlying siltier sediment is not bioturbated. Sample 126-790C-11X-5, 1-21 cm. Scale bar $=1 \mathrm{~cm}$. 
Facies $7901 I_{B}$

The interpretation is the same for Facies $790 \mathrm{II}_{\mathrm{B}}$ as for Facies $792 \mathrm{II}_{\mathrm{C}}$.

\section{BACKARC BASIN-SITE 791}

Site 791 is $2.4 \mathrm{~km}$ east of Site 790 , toward the depocenter of the half-graben (Fig. 3). The sedimentary sequence at this site is Pleistocene in age and is about three times thicker than the time-equivalent section at Site 790 (Fig. 3). Units I and II at this site are correlative both in time and in sedimentary facies with Units I and II at Site 790, although much thicker. The differential subsidence between the two sites is characterized by rates of sedimentation for Unit II at Site 791 that are almost four times those at Site 790 . The sedimentation rate at this site varies from 300 to $2250 \mathrm{~m} / \mathrm{m}$.y. in the last $0.1 \mathrm{~m}$.y.

\section{Unit I}

\section{Description}

Facies in Unit I of Site 791 are the same as they are at Site 790; therefore, they are not redescribed here. Below, the site number only is changed from 790 to 791 . Notable differences between the deposits in Unit I (0-428.4 mbsf; early Pleistocene) and correlative deposits at Site 790 are that coarse-grained sediments form a higher percentage of the succession at Site 791 (Fig. 3), are thicker, and are generally coarser, with clasts up to $7.5 \mathrm{~cm}$ in diameter.

\section{Trace Fossil Assemblages}

Facies $791 I_{A}, 791 I_{B}$, and $791 I_{D}$

Sediments are unbioturbated in Facies $791 \mathrm{I}_{\mathrm{A}}, 791 \mathrm{I}_{\mathrm{B}}$, and $791 \mathrm{I}_{\mathrm{D}}$, as they were in Unit I at Site 790.

\section{Facies $791 I_{C}$}

The deposits of Facies $791 \mathrm{I}_{\mathrm{C}}$ are generally unbioturbated, with the exception of three muddy samples. Sample 126-791A-4H-3, 40-70 cm, contains only few scattered small Chondrites (indexes 2-3). Sample 126-791A-18H-1, 0-65 cm, contains scattered small Chondrites and, in the upper part, a few thin Zoophycos spreiten (indexes 2-3). Sample 126-791A-22H-6, 44-60 cm, defined as Key Bed 7 (Fig. 3) in Taylor, Fujioka, et al. (1990), is highly bioturbated (index 5), Chondrites being the only ichnotaxon present.

\section{Interpretation}

Facies $791 I_{A}, 791 I_{B}$, and $791 I_{D}$

The features of Facies $791 \mathrm{I}_{A}, 791 \mathrm{I}_{B}$, and $791 \mathrm{I}_{D}$ suggest the same interpretation as the equivalent facies of Site 790 .

\section{Facies $791 I_{\mathrm{C}}$}

The primary absence of biogenic structures in the fine-grained sediments can be interpreted being the result of mass-flow deposition, as in the sediments of Facies $790 \mathrm{I}_{\mathrm{C}}$. Pauses or reductions in the volcaniclastic supply favored the few events of colonization, although in disaerobic conditions, as reflected by the dominant ichnotaxon and the reduced size of burrows.

\section{Unit II}

\section{Description}

Unit II facies at Site 791 are equivalent to those in Unit II at Site 790. The major differences within the deposits of Unit II (424.4834 mbsf; early Pleistocene) at Site 790 comprise lithification of the sediment, occurrence of abundant secondary pyrite at a depth from 580 to $770 \mathrm{mbsf}$, and dipping of the beds up to angles of $20^{\circ}$.

\section{Trace Fossil Assemblages}

\section{Facies $791 \mathrm{II}_{\mathrm{A}}$}

The bulk of the muddy sediments in Facies $791 \mathrm{II}_{\mathrm{A}}$ is not bioturbated. The ichnofabrics observed in the scarce burrowed intervals are dominated by Chondrites, Planolites, composite burrows, and Helminthopsis. Zoophycos is less abundant and is represented downcore by thicker spreiten. In addition, Palaeophycus occurs in the lower part of Unit II. Minor changes in the ichnofabric make it possible to distinguish two ichnofabric subfacies: $791 \mathrm{II}_{\mathrm{A1}}$ and $791 \mathrm{II}_{\mathrm{A} 2}$. The boundary is not sharply defined, forming a broad transition zone between Cores 126-791B-35R and -38R.

In Subfacies $791 \mathrm{II}_{\mathrm{Al}}$, the intensity of bioturbation is generally low, having indexes 3 to 2 (Fig. 8), and exceptionally 4 . Trace fossils are concentrated in a few muddy samples, up to $40 \mathrm{~cm}$ thick, whereas most of the fine-grained sediments apparently are unbioturbated (Fig. 9). The suites can be monotypic, comprising small Chondrites, but more frequently they are composed of Chondrites and composite burrows postdating a few indistinctly defined Planolites and laterstage thin Zoophycos spreiten.

The transition zone is characterized by thicker bioturbated intervals of varying diversity and degree of bioturbation. The intensity of reworking is locally high (indexes 5 to 4 ), but mottling does not occur. In Cores 126-791B-35R and -36R, relatively high-diversity assemblages, composed of the same ichnogenera recorded in Subfacies $791 \mathrm{II}_{\mathrm{Al}}$, are represented by slightly compacted, medium- to large-sized structures. These are regularly distributed in a few horizons of $10-40 \mathrm{~cm}$. Downcore, still in the transitional zone, thick intervals containing very scattered Chondrites, or subordinately Chondrites-Planolites (indexes 3 to 2) alternate with thin horizons of numerous Chondrites and unbioturbated sediment.

In Subfacies $791 \mathrm{II}_{\mathrm{A} 2}$, a complex ichnofabric produced by many different generations of burrows characterizes most of the sediment. Burrows are evenly distributed throughout relatively thick intervals, and the density ranges from indexes 4-5 to mottled. The identifiable ichnotaxa are the same as in Subfacies $791 \mathrm{II}_{\mathrm{Al}}$, but with more Palaeophycus, and burrows are less deformed by compaction. Downcore, at depths of 720 mbsf, this subfacies is replaced again by the ichnofabric of Subfacies $791 \mathrm{II}_{\mathrm{Al}}$.

\section{Facies $791 I_{B}$}

Sediments are not bioturbated in Facies $791 \mathrm{II}_{\mathrm{B}}$.

\section{Interpretation}

Facies $791 I_{A}$

The lack of biogenic structures in most of the muddy sediments of Subfacies $791 \mathrm{II}_{\mathrm{Al}}$ can result either from mass-flow deposition or from anaerobic conditions, or more likely from a combination of the two factors. The ichnofossil suites, where present, are suggestive of a generally reduced oxygen content. Variations in density can be related to rapid changes in the rates of sedimentation typical of turbidite environments.

The ichnofacies of the transitional zone are indicative of fluctuations in oxygen content with episodic improvement (samples in Cores 126-791B-35R and -36R) in a normally poorly oxygenated biotope. The lack of a totally bioturbated ichnofabric can depend on a relatively high sedimentation rate of the vitric-rich material that consequently produced a substrate less rich in nutrients. Minor events of mass-flow deposition during a gradual accretion of the bottom as well as variation in the ash supply by fallout can explain the changes in the degree of bioturbation.

The ichnofabric of Subfacies $791 \mathrm{II}_{\mathrm{A} 2}$ documents a coherent substrate, oxygenated water, and a gradual vertical accretion of the seafloor during deposition, accompanied by the upward migration of a tiered endobenthic community. 


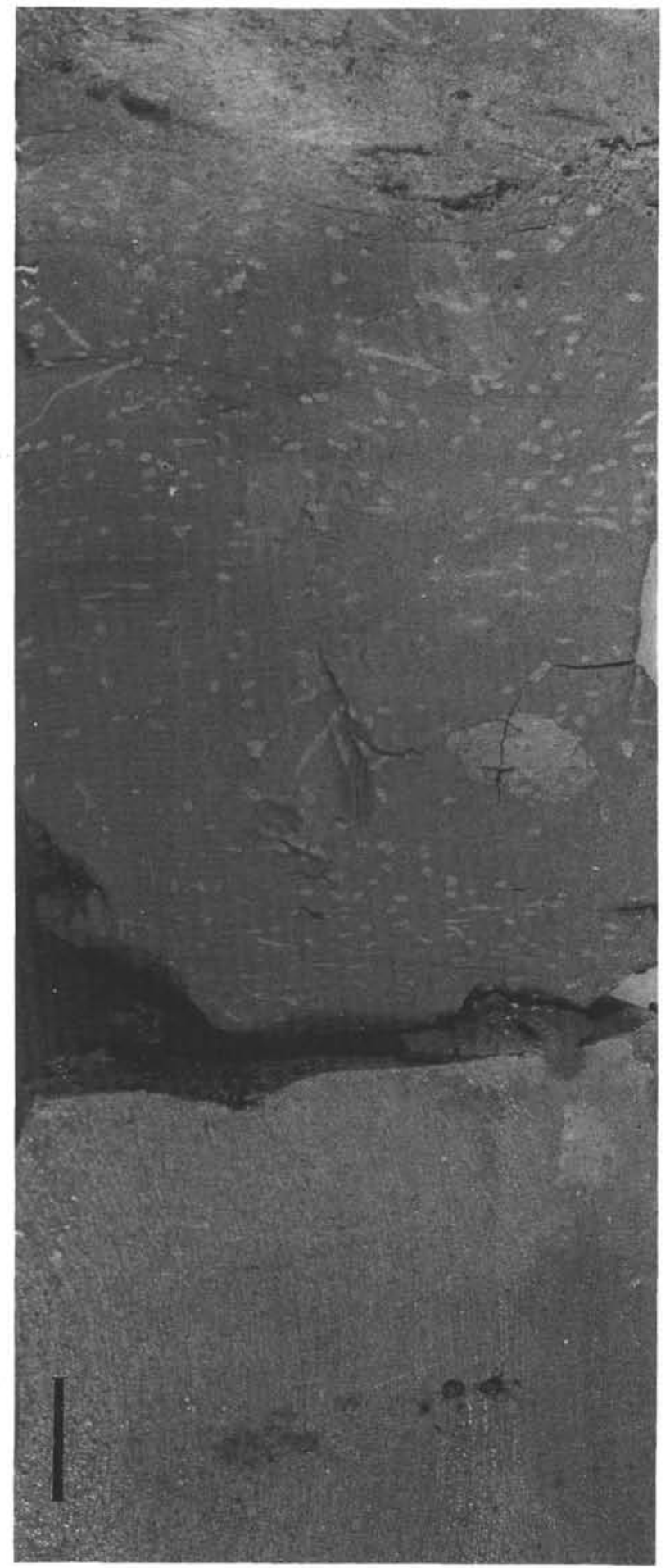

Figure 8. Core photograph, Site 791, Subfacies $791 \mathrm{II}_{\mathrm{Al}}$. Scattered Chondrites in silty claystone overlying an unbioturbated claystone rich in pyrite crystals. The traces reveal opportunism in an oxygen-poor environment. Sample 126791B-25R-2, 2-16 cm. Scale bar $=1 \mathrm{~cm}$.

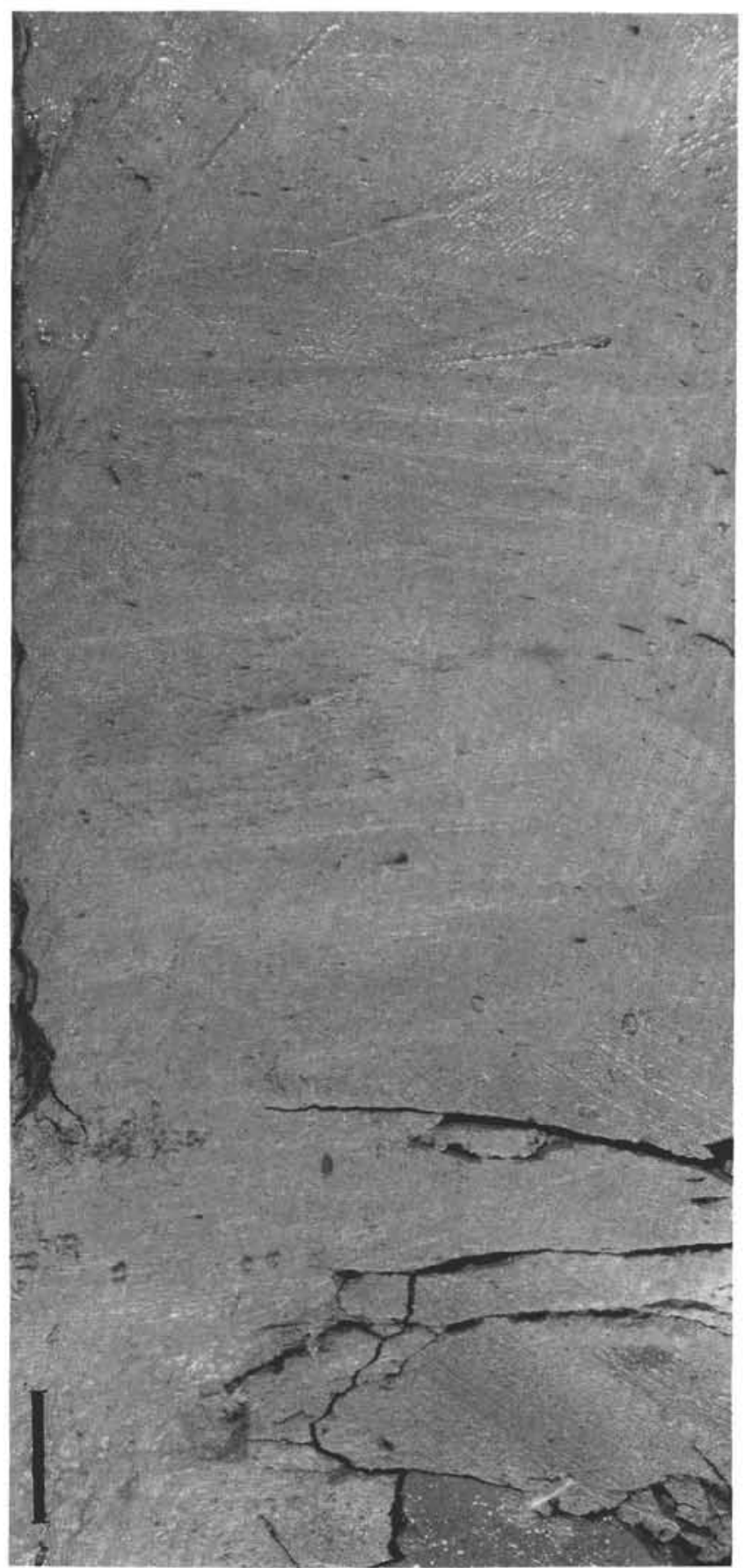

Figure 9. Core photograph, Site 791, Subfacies $791 \Pi_{\mathrm{Al}}$. Unbioturbated claystone. Sample 126-791B-28R-1, 16-28 cm. Scale bar $=1 \mathrm{~cm}$. 
In conclusion, the ichnofabric characters suggest that sediments of this facies were deposited in a generally poorly oxygenated environment with episodically improved conditions. The vertical distribution of traces indicates that fine-grained sediments were emplaced both by hemipelagic processes and turbidite currents. The frequency of the turbidite input strongly decreases down succession; in particular, the transition zone marks a change from a turbidite-current-dominated to a hemipelagic-dominated depositional environment. In the basal part of the sedimentary sequence (from Core 126-791B-44R to the bottom), a turbidite-current-dominated setting is abruptly reestablished in a well-oxygenated environment.

\section{Facies $791 I_{B}$}

The interpretation is the same for Facies $791 \Pi_{\mathrm{B}}$ as for Facies $792 \mathrm{II}_{\mathrm{C}}$.

\section{EASTERN FOOTWALL UPLIFT-SITE 788}

Site 788 is located on the summit of the eastern footwall flank of the Sumisu Rift (Figs. 2 and 3). The 374-m-thick sedimentary succession, Pliocene to Quaternary in age, consists of two stratigraphic units, dominated by coarse-grained volcaniclastic deposits (Fig. 10).

\section{Unit I}

\section{Description}

Unit I (0-249 mbsf; Pliocene-Quaternary) comprises thick to very thick beds of dark pumiceous gravel and conglomerate, locally interbedded with sands and silts. The beds are structureless and lack bioturbation. A progressive change in lithification from gravel to conglomerate occurs downhole and has been a criterion for dividing the unit into two subunits at $229.2 \mathrm{mbsf}$. Unit I was deposited between the present and $3.8 \mathrm{Ma}$ on a submarine structural high. An unconformity, probably related to the uplift of the footwall, is placed at $30 \mathrm{mbsf}$ between pumice gravel younger than $275 \mathrm{ka}$ and pumice gravel older than $2.35 \mathrm{Ma}$. Because bioturbation is absent, no facies in Unit I are distinguished in this paper.

\section{Unit II}

\section{Description}

Unit II (249-374 mbsf; Pliocene) is a 125-m-thick succession that has been divided in two subunits (limit at $278.6 \mathrm{mbsf}$; Fig. 10) based on the absence (IIA) and presence (IIB) of conglomerate. It comprises three facies.

\section{Facies $788 I_{A}$}

Facies $788 \mathrm{II}_{\mathrm{A}}$ is composed of beds of poorly sorted black pumiceous conglomerate with a sandy matrix and maximum clast sizes of about $10 \mathrm{~mm}$.

\section{Facies $788 I_{B}$}

Facies $788 \Pi_{B}$ is made up of thin to medium beds of grayish black vitric sandstone and siltstone. Beds are commonly parallel laminated and graded; locally, the siltstone beds appear structureless or bioturbated.

\section{Facies $788 I_{C}$}

Very thin to medium beds of mudstone and nannofossil-rich claystone locally containing glauconite comprise Facies $788 \mathrm{II}_{\mathrm{C}}$ Foraminifer and nannofossil tests are clearly visible.

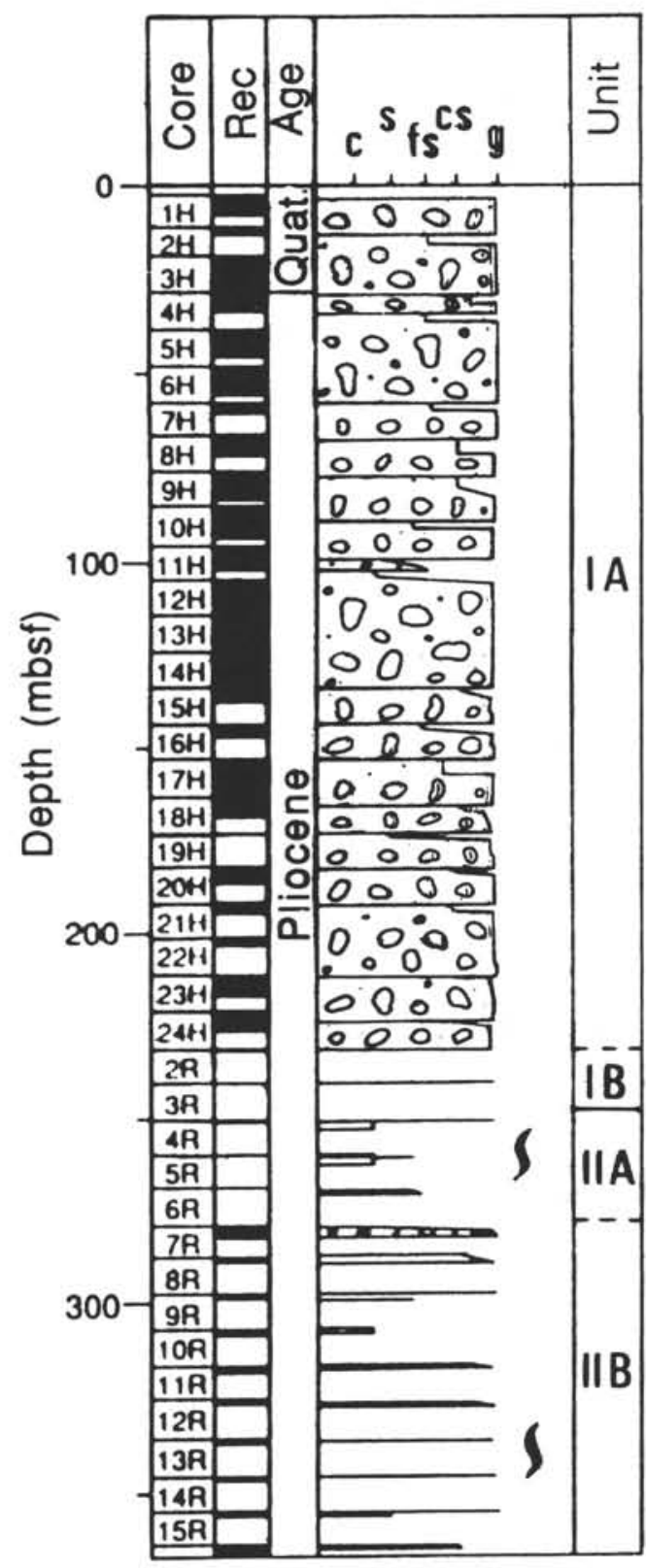

Figure 10. Composite stratigraphic section for Site 788 showing unit boundaries.

\section{Trace Fossil Assemblages}

Facies $788 I_{A}$

Sediments are not bioturbated.

Facies $788 \mathrm{II}_{B}$

Sediments are generally unbioturbated. Secondary burrows are locally present in the topmost part of these beds.

\section{Facies $788 I_{C}$}

Records of organic activity are restricted to a few fine-grained intervals in Facies $788 \mathrm{II}_{\mathrm{C}}$, in particular in Core 126-788D-5R-1 of 
Subunit IIA and in Cores 126-788D-9R, -9R-CC, and -16R-1 of Subunit IIB. The first interval is about $2 \mathrm{~m}$ thick; the last two, 10 and $15 \mathrm{~cm}$, respectively. However, because the recovery of fine-grained sediment at this site is very limited, a certain number of bioturbated horizons could have been lost.

The identified ichnotaxa are the following: two-sized Chondrites; thick Zoophycos spreiten; slightly compacted, sharply delimited Planolites; locally abundant Helminthopsis; and Palaeophycus. Composite burrows are well represented also. Sediments of Subunit IIA, characterized by the higher diversity assemblage, show the unique occurrence of Scolicia and Skolithos, which both postdate all the other traces (Fig. 11); the latter ichnotaxon can be found alone (Fig. 12). The number density of the burrows can be either constant or, less commonly, vertically variable, ranging from 2 to $4-5$ upward in 10 to 20-cm-thick layers that are generally unbioturbated in the few basal centimeters; totally bioturbated ichnofabric is rare. In the lower bioturbated interval (Subunit IIB), the ichnofacies comprises different systems of Zoophycos, with large pelleted spreiten that cross-cut each other and postdate Chondrites.

\section{Interpretation}

Facies $788 I_{A}$

The pumiceous conglomerate present in Facies $788 \mathrm{II}_{\mathrm{A}}$ was produced by active rhyolitic volcanism. As for sediments of Facies $788 \mathrm{II}_{B}$, the depositional processes responsible for emplacement of these sediments are still unclear.

\section{Facies $788 I I_{B}$}

The sediments were produced by regional volcanicity.

\section{Facies $788 I_{C}$}

The evenly bioturbated horizons of Subunit IIA testify to favorable living conditions on an oxygenated, gradually accreting seafloor. Episodic events of moderate to relatively high hydrodynamism, possibly caused by the flow of weak bottom currents, are suggested by the presence of Scolicia and Skolithos. The laminated to bioturbated pattern usually indicates pulses in the rate of sedimentation (Howard, 1978). However, an alternative hypothesis can be suggested in this case. The lack of trace fossils in the laminated part of the bioturbated layers, as well as in the numerous totally unbioturbated laminated intervals, could be related to episodic scouring of the seafloor by bottom currents, as already suggested by the presence of glauconite and the relative abundance of foraminifers with respect to nannofossils (Taylor, Fujioka, et al., 1990). In Subunit IIB the cross-cutting relations of the apparently low-ichnodiversity Zoophycos assemblage (Fig. 13) point to a vertical migration of spreiten that could produce a complete obliteration of the shallower tier traces (Bromley, 1990). Consequently, the ichnofacies suggests deposition on a moderately oxygenated, low-energy sea bottom characterized by a lower hydrodynamism than during the deposition of Subunit IIA.

\section{FOREARC BASIN-SITE 792}

Site 792 is located on the western side of the Izu-Bonin forearc sedimentary basin (Fig. 2). The sedimentary succession, Pleistocene to early Oligocene in age, consists of $804 \mathrm{~m}$ of volcanogenic and biogenic materials that lie on an igneous basement (Fig. 14). Five stratigraphic units have been recognized in the sedimentary sequence.

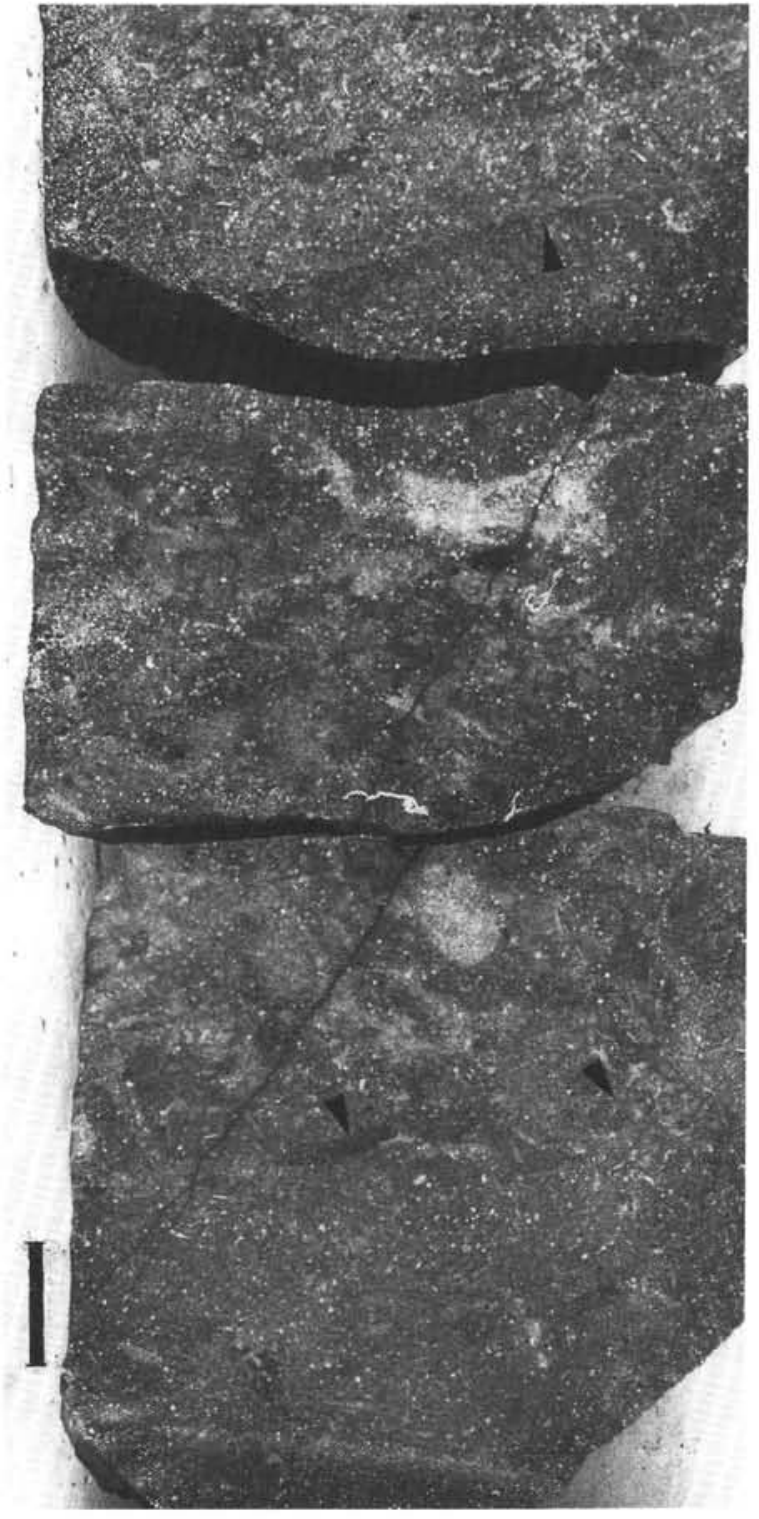

Figure 11. Core photograph, Site 788, Facies $788 \mathrm{II}_{\mathrm{C}}$. Claystone interval intensely bioturbated by Chondrites and Planolites. Postdating meniscate traces (arrowed) occur. Sample 126-788D-5R-1, 53-66 cm. Scale bar $=1 \mathrm{~cm}$.

\section{Unit I}

\section{Description}

Sediments in Unit I (0-183.7 mbsf; late Pliocene to Holocene) are dominated by bioturbated nannofossil-rich mud. Four facies have been recognized.

\section{Facies $792 I_{A}$}

Thin to medium beds of scoriaceous and pumiceous, pebble to granule gravel occur in the upper part of Facies $792 \mathrm{I}_{\mathrm{A}}$ in Unit I. 


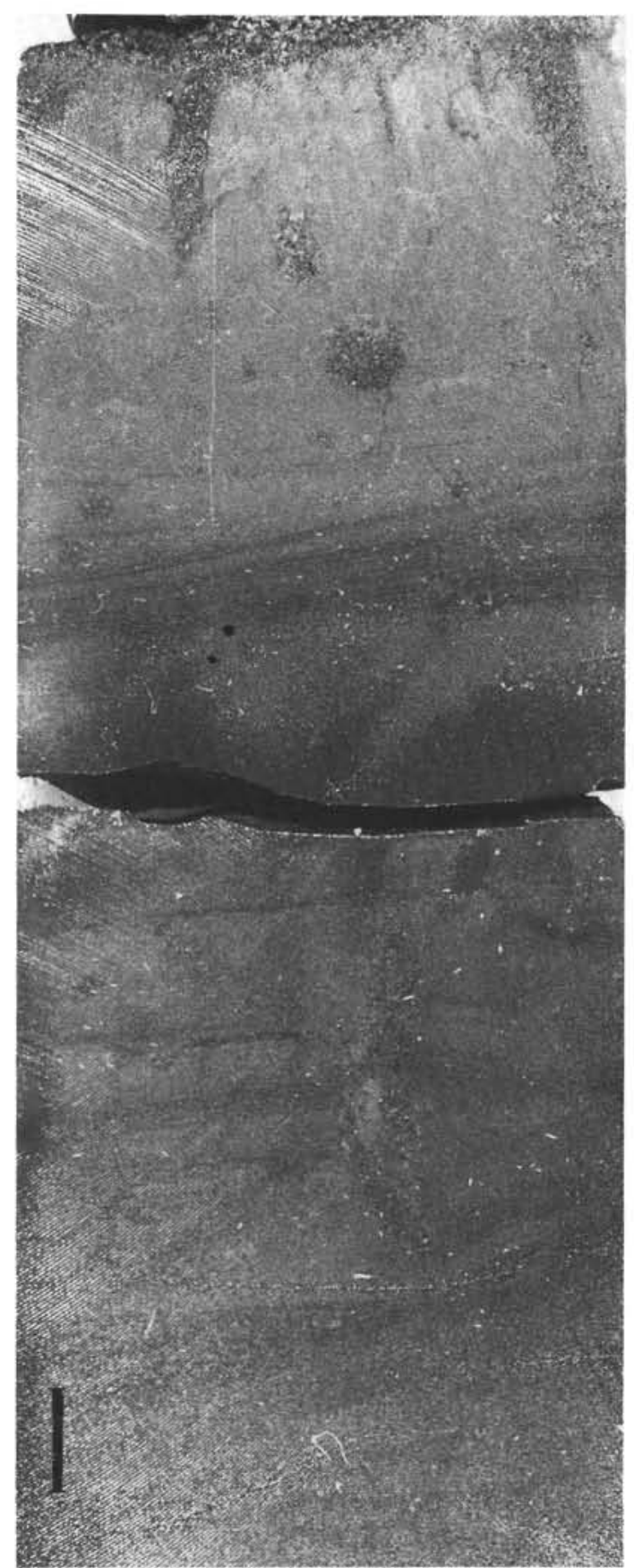

Figure 12. Core photograph, Site 788, Facies $788 \mathrm{II}_{\mathrm{C}}$. Skolithos passively filled by sandstone in an otherwise unbioturbated mudstone. Sample 126-788D-5R-1, $15-29 \mathrm{~cm}$. Scale bar $=1 \mathrm{~cm}$.

\section{Facies $792 I_{B}$}

Facies $792 I_{B}$ is composed of thin to medium, sharp-based beds of dark vitric sand and silt locally grading into mud. Several beds show normal grading and parallel and/or cross lamination.

\section{Facies $792 I_{C}$}

Facies $792 \mathrm{I}_{\mathrm{C}}$ is made up of thin to thick beds of bioturbated nannofossil-rich mud with scattered volcanic fragments.

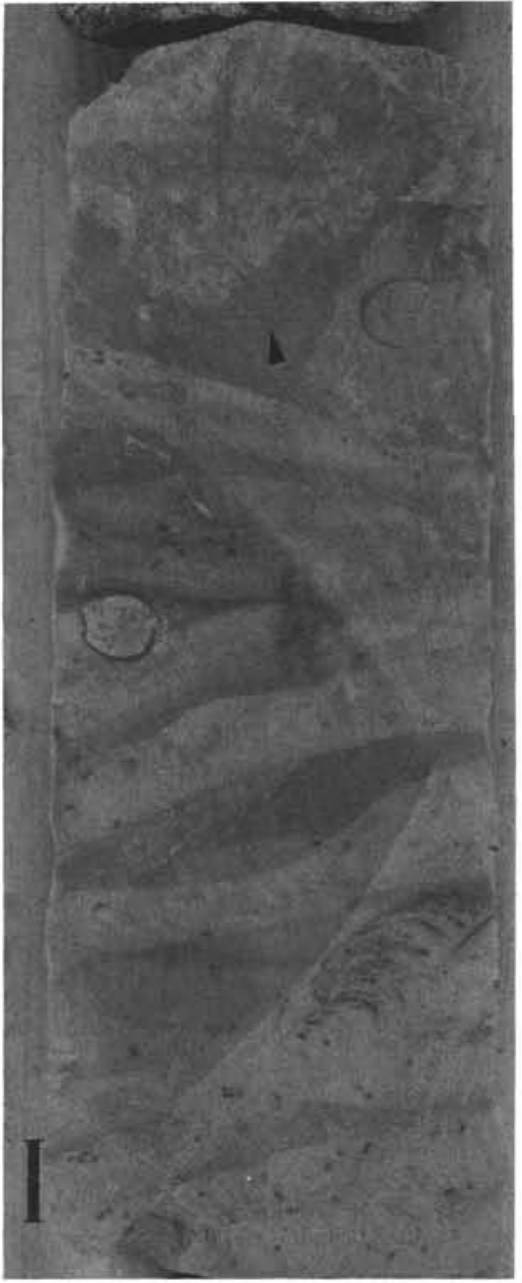

Figure 13. Core photograph, Site 788, Facies $788 \mathrm{II}_{\mathrm{C}}$. Zoophycos-dominated assemblage. Densely packed Chondrites (arrowed) in the upper part of the figure. Sample 126-788D-16R-1, $15-29 \mathrm{~cm}$. Scale bar $=1 \mathrm{~cm}$.

\section{Facies $792 I_{D}$}

Very thin to thin, sharp-based beds of grayish green to white ash are scattered in the other sediments of Facies $792 \mathrm{I}_{\mathrm{D}}$.

\section{Trace Fossil Assemblages}

Facies $792 I_{A}$ and $792 I_{D}$

Trace fossils are absent.

\section{Facies $792 I_{B}$}

The deposits are generally lacking in biogenic structures, but a few burrows are found at the top of beds that have a muddy upper division.

\section{Facies $792 I_{C}$}

The degree of biogenic reworking in Facies $792 \mathrm{I}_{\mathrm{C}}$ is generally low (indexes 2 or 3 ), although somewhat higher in the muddier sediments; intensely bioturbated or mottled horizons are uncommon. Minor vertical changes in the density of burrows in a single bed normally occur, but a constant trace fossil density throughout the sediment is not rare. 


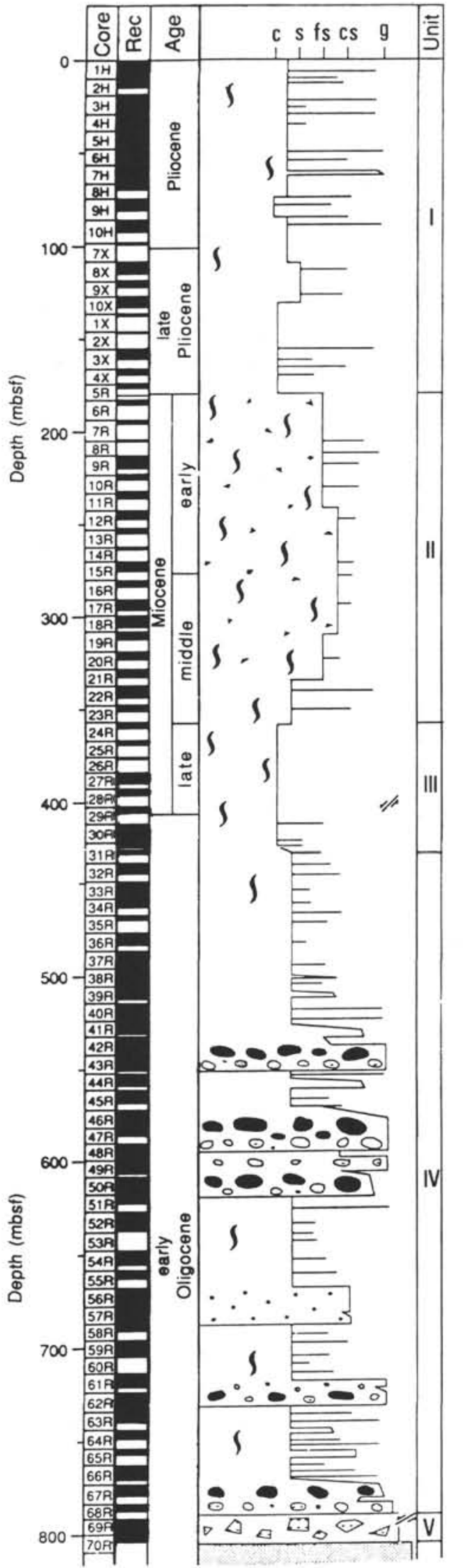

Figure 14. Composite stratigraphic section for Site 792 showing unit boundaries.
The ichnotaxa are represented by medium- and large-sized Planolites and Chondrites, commonly associated to form a low-diversity assemblage in which the second component postdates the first one. Rarely the suites are monotypic, composed either of Chondrites or Planolites. The traces are generally emplaced in the upper part of the burrowed beds, but the ratio between bioturbated vs. unbioturbated sediments in the same bed is highly variable, ranging from a reworking restricted to the topmost few millimeters to a largely dominant bioturbated part. The values of this ratio commonly fall between 0.7 and 0.9 , but evenly bioturbated beds (ratio $=1$ ), in a few cases up to $60-70 \mathrm{~cm}$ thick, are not uncommon.

\section{Interpretation}

Facies $792 I_{A}$ and $792 I_{B}$

The absence of biogenic structures in Facies $792 \mathrm{I}_{\mathrm{A}}$ and $792 \mathrm{I}_{\mathrm{B}}$ can reflect an original lack of endobenthic activity ensuing from stress factors that can be singled out in the prevalent organic-depleted volcanic clasts and in their high rate of deposition caused by sediment gravity flows.

\section{Facies $792 I_{C}$}

Cross-cutting relations and distribution of burrows in the muddy intervals of Facies $792 \mathrm{I}_{\mathrm{C}}$ suggest short events of sudden deposition, recorded by the occasionally unbioturbated basal part of the beds. These were followed by longer periods of gradual accretion of the seafloor during which the volcaniclastic input was more or less reduced but not absent. Indeed, as the main negative factor preventing a complete reworking of the substrate can be considered the continuous fallout of volcaniclastic material exceeding the burial rate of nutrients, it produced an organic-poor sediment that accumulated at a relatively high rate. Fluctuations in the supply reasonably governed the changes in the degree of bioturbation. The same stress factor could be responsible for the low ichnodiversity. Depletion in oxygen has been excluded on the basis of data from the benthic foraminifers; the large size of burrows supports this conclusion. A further disturbing factor is represented by the frequency of volcanogenic killing events.

Facies $792 I_{D}$

The interpretation is the same for Facies $792 \mathrm{I}_{\mathrm{D}}$ as for Facies $792 \mathrm{II}_{\mathrm{C}}$.

\section{Unit II}

\section{Description}

Unit II (183.7-357.4 mbsf; middle and late Miocene) consists mainly of poorly sorted sandy mudstone and muddy sandstone containing granules and pebbles. In particular, three facies were recognized.

Facies $792 I_{A}$

Facies $792 \mathrm{II}_{\mathrm{A}}$ is composed of thin to thick beds of dark nannofossil-rich sandy mudstone, muddy sandstone, and mudstone with disseminated grains of brown basaltic scoria, rhyolite pumice, clear volcanic glass shards, and volcanic rock fragments.

\section{Facies $792 I_{B}$}

Facies $792 \mathrm{II}_{\mathrm{B}}$ is made up of very thin to thin sharp-based beds of dark sandstone and siltstone that are structureless, graded, or parallel laminated.

\section{Facies $792 I I_{C}$}

Rare, very thin to thin, sharp-based beds of grayish green to white ash are limited to the upper part of Facies $792 \mathrm{II}_{\mathrm{C}}$. 


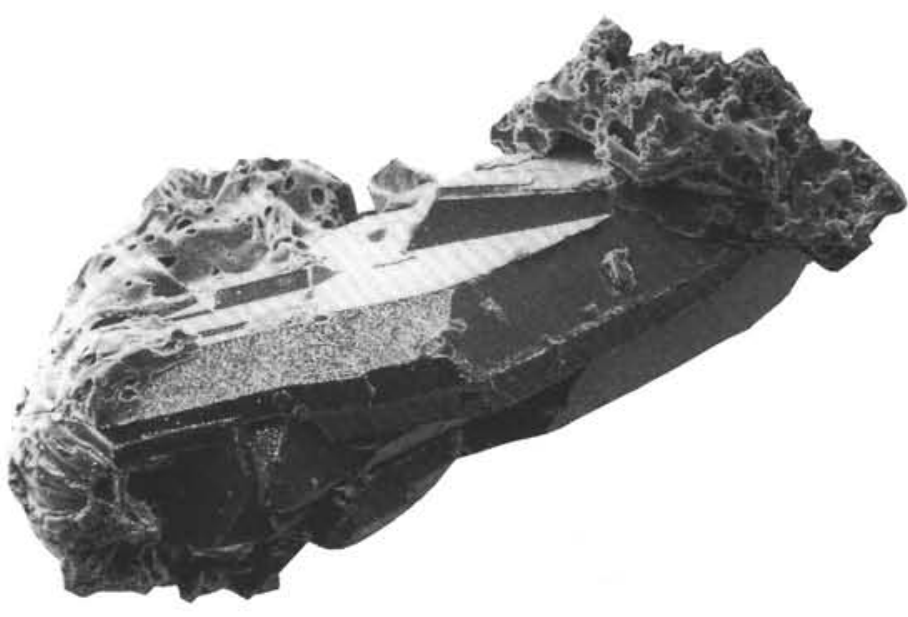

$500 \mu \mathrm{m}$

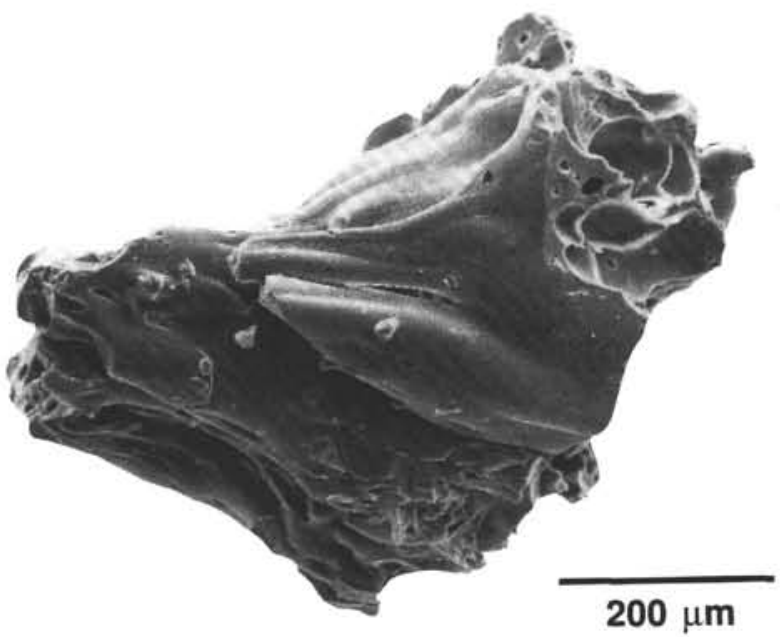

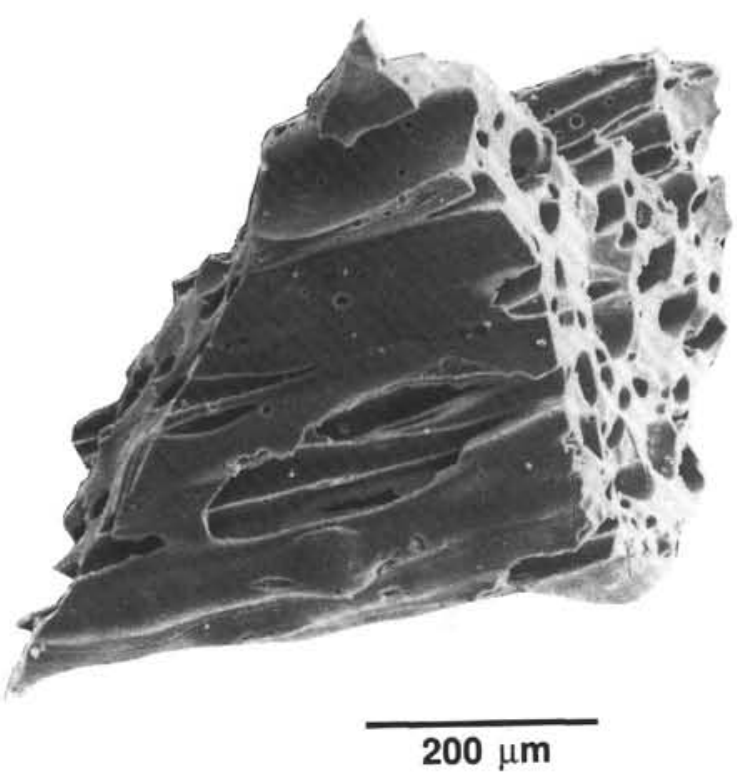

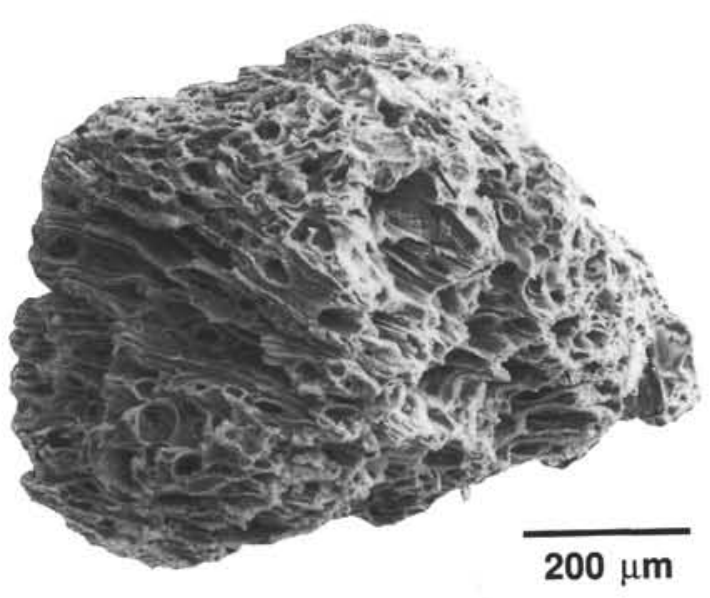

Figure 15. SEM images of selected pyroclastic grains of Sample 126-792E-12R-1, 100-102 cm, showing fresh and clean surfaces.

\section{Petrography and Morphoscopy}

Facies $7921 I_{A}$

Two samples of poorly sorted, massive, muddy sandstone were examined, producing contrasting results. Sample 126-792E-12R-1, $100-102 \mathrm{~cm}$, is mainly composed of glassy fragments and loose crystals of plagioclase and clinopyroxene. The glassy component consists dominantly of brown grains together with fluidal pumiceous grains. SEM images show volcanic grains with fresh clean and smooth surfaces. They consist of vesiculated glass fragments with highly fluidal shapes and very fresh unbroken crystal fragments. The grains do not show edge modifications, chemical etching, or fluid condensation effects (Fig. 15).

Sample 126-792E-12R-1, 50-52 cm, is mainly composed of sand-sized fragments of dense opaque scoria with plagioclase and clinopyroxene phenocrysts, brown glassy grains, and clasts of volcanic mud, SEM images show that most of the grains have blocky shapes with edge and chemical surface modifications represented by diffuse pitting, film overgrowths, and particle adherence (Fig. 16).

\section{Facies $792 \mathrm{II}_{C}$}

The petrographic and morphoscopic analysis of a thin ash layer (Sample 126-792E-12R-1, 85-87 cm) shows that the composition of this layer is monogenic, consisting of sand-sized clear glass grains. Observations on thin sections document that these grains are "pellets" of volcanic mud, produced by the accretion of fine ash particles locally around clasts of benthic foraminifers. SEM images (Fig. 17) show how almost all the grains have blocky shapes with edge modifications produced by mechanical abrasion and chemical surface modifications caused by diffuse pitting, film overgrowths, and abundant particle adherence.

\section{Trace Fossil Assemblages}

Facies $792 \mathrm{II}_{\mathrm{A}}$

Changes in the ichnofabric make it possible to divide this facies into two ichnofabric subfacies that have a sharp contact with one another.

Subfacies $792 \mathrm{II}_{\mathrm{Al}}$ (Cores 126-792E-6R to -17R). The presence of numerous volcaniclastic elements of different nature and size, scat- 

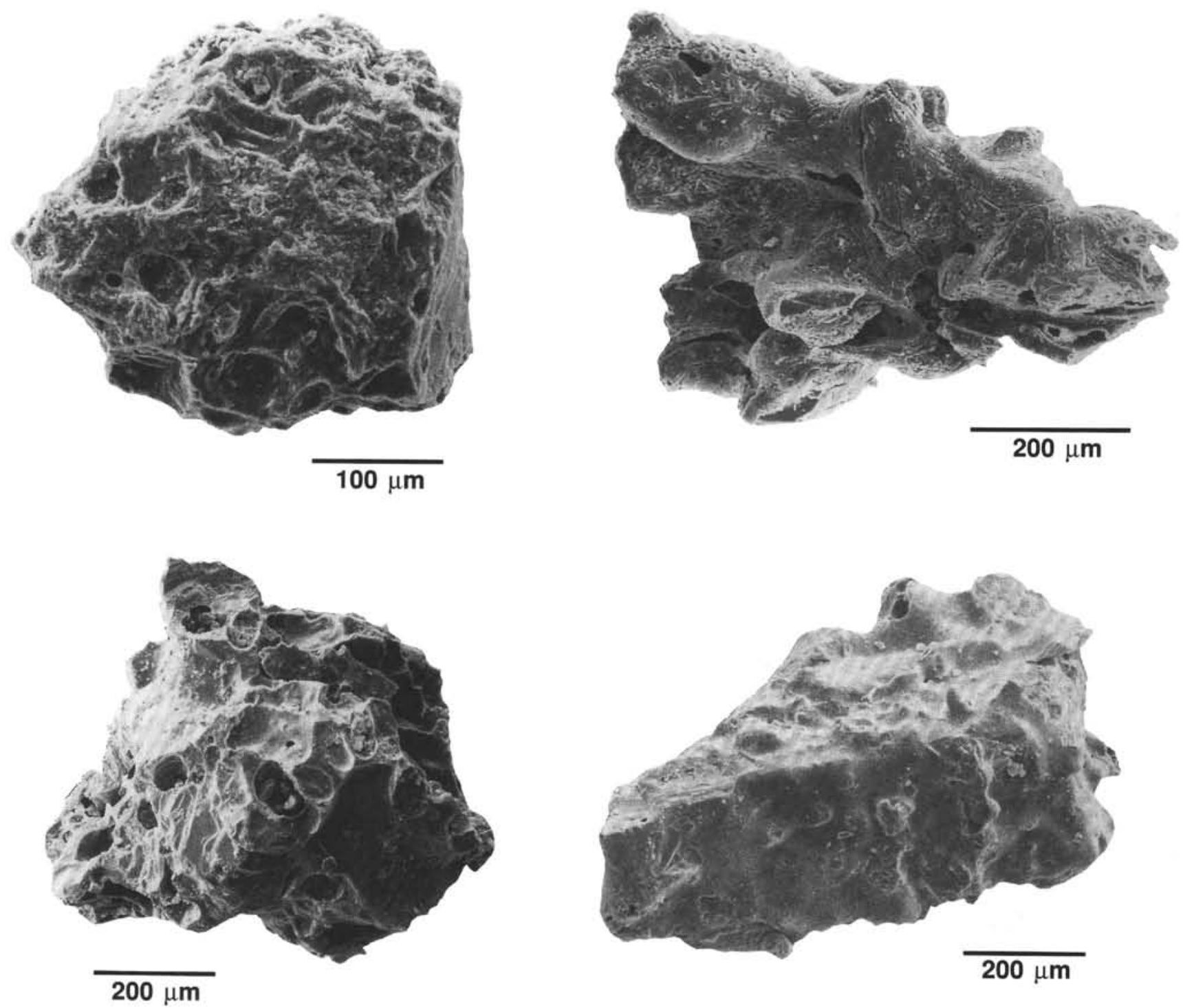

Figure 16. SEM images of selected pyroclastic grains of Sample 126-792E-12R-1, 50-52 cm, showing surface modifications represented by diffuse pitting, film overgrowths, and particle adherence.

tered in the sediment, locally produces a confused fabric (Fig. 18) and makes it hard to judge the degree of reworking; in a few cases, the existence of biogenic structures is questionable. Commonly, the trace fossils are evenly distributed in the bed, but they can be restricted into thin horizons, apparently in relation to the quantity and size of volcanic grains. Completely unbioturbated sediments are not rare. Overall, a low ichnodiversity and density of bioturbation (indexes 3 to 2) are the distinctive features of Subfacies $792 \mathrm{I}_{\mathrm{Al}}$. Medium- to large-sized Planolites and Chondrites occur throughout the bioturbated intervals, and occasionally Chondrites is replaced by small sinuous unwalled galleries (Helminthopsis). Locally (Core 126-792E$17 \mathrm{R})$, rare composite burrows can be found.

Subfacies $792 I_{\mathrm{A} 2}$ (Cores 126-792E-18R to -23R). Intense and extensive biogenic reworking, as well as a higher ichnodiversity characterize this subfacies. The trace fossils found are as follows: abundant Planolites, Chondrites, and Helminthopsis, few Zoophy$\cos$, rare Taenidium, and Palaeophycus. Furthermore, composite burrows represented by Planolites-fill reworked by Helminthopsis occur frequently. A few observations on two ichnotaxa are required.
1. Rare subelliptic cross-sections of tunnels having structureless fills, different from the surrounding sediment, and walls made by black grains, can be attributed to Palaeophycus. However, the "wall" could represent a boundary concentration by Planolites-makers; the features of filling are not diagnostic, and it could have been previously used by the organisms or passively absorbed into abandoned galleries.

2 . The presence of Thalassinoides is debatable. In cross-sections Thalassinoides is commonly identified by an asymmetrical fill-structure (Wetzel, 1987); however, in the few dubious "Thalassinoides" cross-sections observed in this subfacies, the fills are intensely reworked by Helminthopsis so that the diagnostic features, even if they existed, have been lost.

The size of the trace fossils has a wide range, but the medium and large forms are more widespread than the small ones. The number density of bioturbation generally fluctuates from high to very high ( 5 to 4) and mottled intervals are not rare, so that juxtapositions of many different generations of burrows are the rule. Generally, the biogenic structures are evenly distributed throughout thick beds (Fig. 19). 


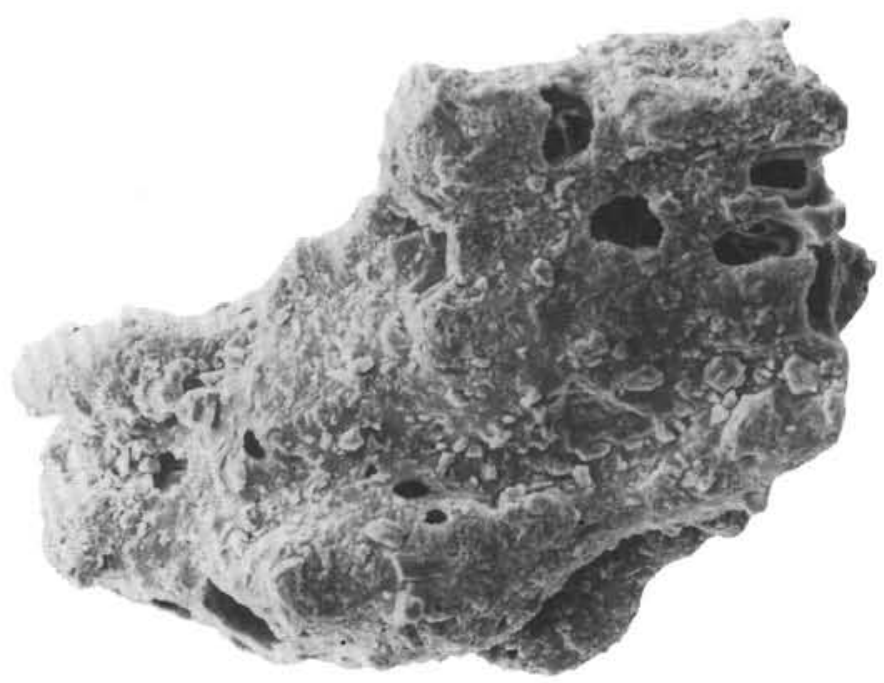

$100 \mu \mathrm{m}$

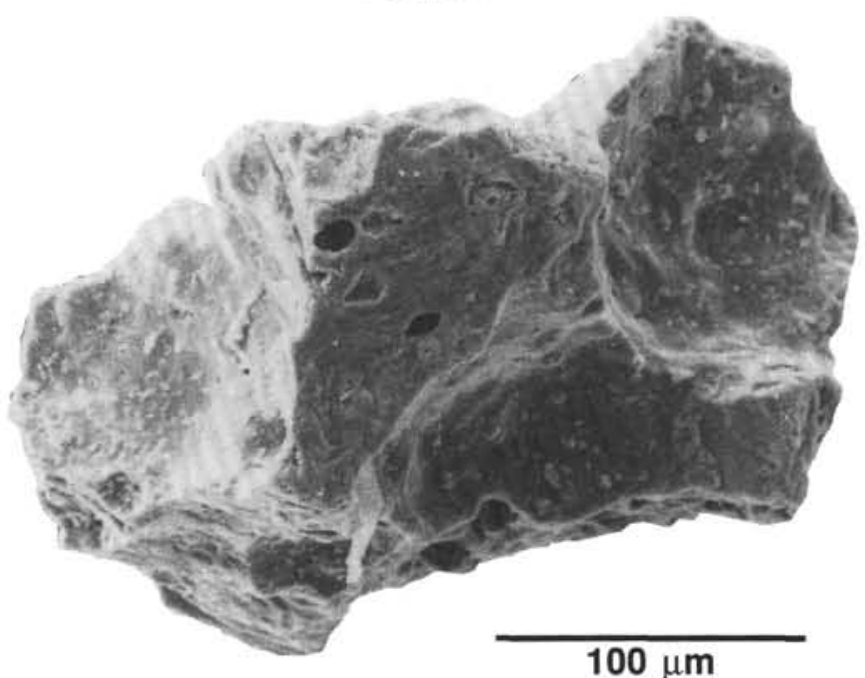

$100 \mu \mathrm{m}$
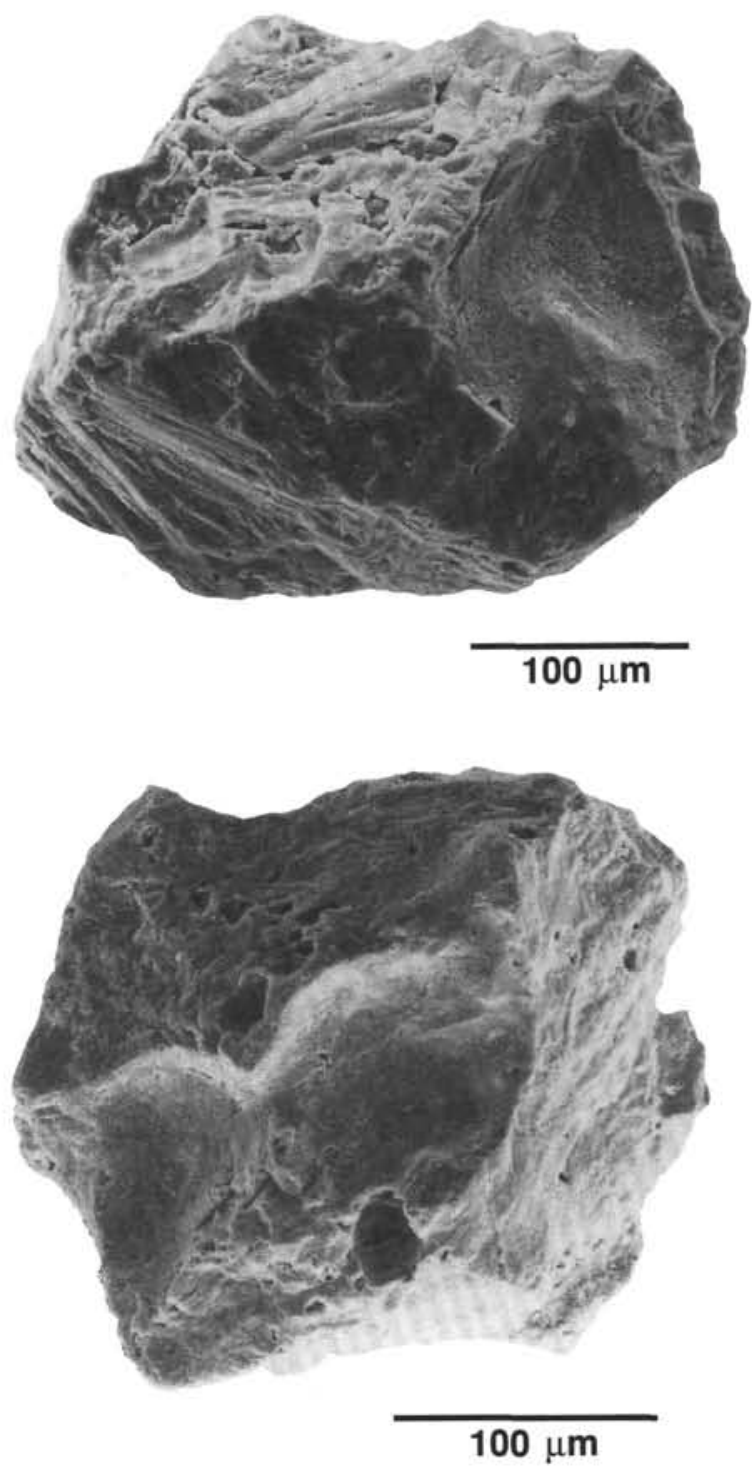

Figure 17. SEM images of selected pyroclastic grains of Sample 126-792E-12R-1, $85-87 \mathrm{~cm}$, showing the blocky shape of the grains and edge modifications produced by chemical surface modifications.

Episodes of upward increases of reworking intensity are rarely documented. In some cases, thin layers of dark siltstone interbedded with thick nannofossil-rich mudstone are almost completely obliterated by the biogenic reworking; however, they can still be easily identified. Unbioturbated millimetric horizons composed of volcaniclastic material are rare. The trace fossil assemblage represents high-ichnodiversity, Planolites-dominated, less frequently Chondrites-dominated suites.

\section{Facies $792 I_{B}$}

Facies $792 \mathrm{II}_{\mathrm{B}}$ is generally unbioturbated. Exceptionally, a few Chondrites are present in the top part of thin clayey siltstone beds.

\section{Facies $792 I I_{C}$}

The beds are not bioturbated.

\section{Interpretation}

Facies $792 I_{A}$

The characters of the ichnofabric, as well as the petrography and morphoscopy of the volcanic grains, indicate that the massive aspect of this facies is partly a result of the fallout of biogenic material and poorly sorted pyroclastic sediment, and partly caused by biogenic reworking of the hemipelagic beds with thin beds of pyroclastic material emplaced by sediment gravity flows.

In Subfacies $792 \mathrm{II}_{\mathrm{A} 1}$, the features of the ichnofabric suggest depositional setting conditions somewhat similar to those of Unit 792 I; that is, long periods of sediment fallout interrupted by sudden incursions of sediment gravity flows. The main differences consist of a generally lower degree of bioturbation and a higher frequency and increased thickness of the bioturbated intervals. This is probably a result of the higher rate of sedimentation and a more constant 


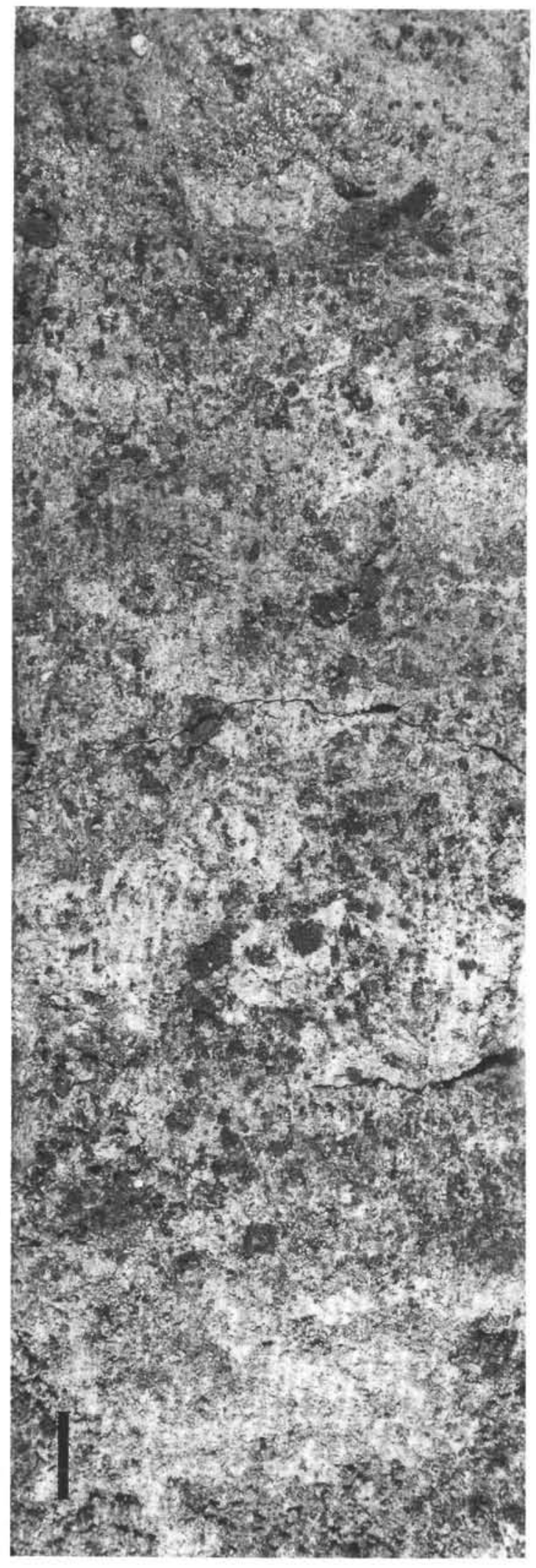

Figure 18. Core photograph, Site 792, Subfacies $792 \mathrm{II}_{\mathrm{Al}}$. Poorly bioturbated, granule-rich, muddy sandstone. Pumice grains and black scoria mimic the biogenic structures. Sample 126-792E-12R-1, 103-121 cm. Scale bar $=1 \mathrm{~cm}$.

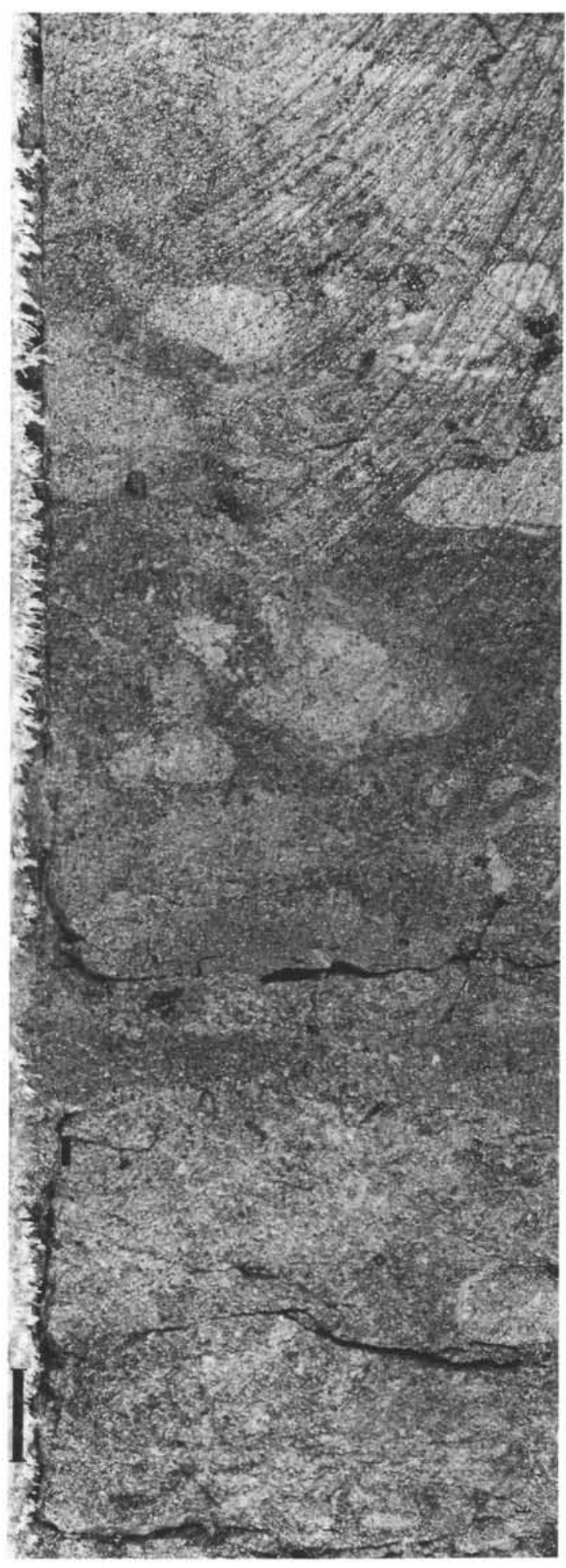

Figure 19. Core photograph, Site 792, Subfacies $792 \mathrm{II}_{\mathrm{A} 2}$. Typical ichnofabric of this subfacies. Sharply defined Planolites and composite burrows are emplaced on a bioturbated background. Sandy mudstone bed. Sample 126$792 \mathrm{E}-18 \mathrm{R}-4,44-61 \mathrm{~cm}$. Scale bar $=1 \mathrm{~cm}$. 
supply of volcaniclastic material from fallout, which periodically raised the starvation conditions to the limit of community survival.

In Subfacies $792 \mathrm{II}_{\mathrm{A} 2}$, the more extensive bioturbation is the result of improved life conditions, mainly controlled by a raised availability of nutrients, decreased rate of sedimentation, and longer periods of stability at the seafloor. Complex cross-cutting relations, as well as high and quite constant values of burrow density in the thick sedimentary intervals, point to a slow and gradual upward migration of the tiered infaunal community, as a result of long-lasting regular accretion of the sea bottom. Most of the scattered volcaniclastic grains must have been deposited at a low rate by fallout, then mixed with the pelagic material. Variations in favor of the sandy input are documented both by the reduction of the burrowing activity and the raised concentration of the volcaniclastic material.

In conclusion, the sediments of this facies are thought to have been emplaced primarily by hemipelagic input of a mixed pelagic and pyroclastic material, and subordinately by turbidite currents. A biogenic mixing of hemipelagic mud with thin beds of suddenly deposited coarser sediment is not likely to have been the only or the most important formative process of the massive muddy sandstone and sandy mudstone (see Taylor, Fujioka, et al., 1990). In Subfacies $792 \mathrm{II}_{\mathrm{Al}}$, richer in coarse grains and volcanic material than Subfacies $792 \mathrm{II}_{\mathrm{A} 2}$, a total biogenic homogenization of lithologically different beds is hard to justify, the intensity of reworking being inadequate. In Subfacies 792 $\Pi_{\mathrm{A} 2}$, for all the high density of traces, episodes of mass-flow deposition are generally still discernible, either by a greater concentration of dark glass grains or by the partial preservation of thin beds. We therefore conclude that most of the muddy sandstones and sandy mudstones are primary hemipelagic mixtures, whereas others are secondary biogenic mixtures caused by the burrowing of hemipelagic deposits and volcaniclastic turbidites. This interpretation is supported also by the morphoscopic characteristics of the pyroclastic grains. In Sample 126-792E-12R-1, 100-102 cm, the morphoscopy indicates that the grains have been supplied to the seafloor by the fallout of pyroclastic material directly ejected into water by high-energy, explosive activity on land. The morphoscopic data of Sample 126-792E$12 \mathrm{R}-1,50-52 \mathrm{~cm}$, macroscopically similar to the previous one, confirm that part of the massive sediment is a result of biogenic reworking of hemipelagic mud with turbidites of coarser pyroclastic sediment. The surface of the grains, in fact, show modifications produced by the submarine flow of pyroclastic detritus.

\section{Facies $792 I_{B}$}

Sediments in Facies $792 \mathrm{II}_{\mathrm{B}}$ are thought to have been deposited by sediment gravity flows.

\section{Facies $792 I_{C}$}

The petrographic, morphoscopic, and sedimentologic characters (sharp or erosional bases, grading, lamination) in Facies $792 \mathrm{II}_{\mathrm{C}}$ suggest that these ash layers have been emplaced by turbidite currents of pyroclastic homogeneous material. This material was temporarily parked in a nearshore area before being resedimented in a basinal site, as suggested by the presence of bioclasts of benthic foraminifers in the "pellets" of volcanic mud. The vitric nature of the sediment, the lack of organic matter, and the rapid deposition inhibited the development of biologic communities in these beds.

\section{Unit III}

\section{Description}

Unit III (357.4- $429.3 \mathrm{mbsf}$; early Miocene to early Oligocene) is the finest grained unit of the succession with the highest content of calcium carbonate. It comprises two facies.
Facies $792 \mathrm{III}_{\mathrm{A}}$

Facies $792 \mathrm{II}_{\mathrm{A}}$ is composed of thin to thick beds of intensely burrowed, nannofossil-rich to nannofossil claystone and nannofossil chalk.

\section{Facies $792 \mathrm{III}_{B}$}

Facies $792 \mathrm{III}_{\mathrm{B}}$ is made up of erosional or sharp-based, very thin to thin beds of dark sandstone and siltstone showing Bouma (1962) sequences. The beds grade upward into mudstone and become more abundant down in the unit.

\section{Trace Fossil Assemblages}

\section{Facies $792 \mathrm{III}_{\mathrm{A}}$}

This facies is characterized by highly bioturbated to mottled thick intervals; on the basis of the dominant lithology and features of ichnofabrics, it can be divided into three subfacies.

In Subfacies $792 \mathrm{III}_{\mathrm{Al}}$ (Cores 126-792E-24R to -26R), the dominant ichnogenera are medium- to large-sized Planolites and Chondrites, which are represented by many different generations of burrows that produce a highly bioturbated ichnofabric. The burrowing number density is vertically variable from 2 to 4 or 5 , in relation to lithologic differences; the higher values, up to mottling, are recorded in the nannofossil-rich claystone. The beds, $10-20 \mathrm{~cm}$ thick, commonly grade downward into less intensely bioturbated ( 3 to 2 ), thin intervals of nannofossil-claystone and/or unbioturbated siltstone.

The boundary with the underlying subfacies is quite sharp. In Subfacies $792 \mathrm{III}_{\mathrm{A} 2}$ (Cores 126-792E-27R to -28R), thick beds of nannofossil chalk and nannofossil claystone are evenly and highly bioturbated or mottled (Fig. 20). The trace fossil assemblage forms a complex ichnofabric of successive cross-cutting burrows dominated by Planolites of different sizes associated with large Chondrites and less abundant Zoophycos. Downcore the nannofossil chalk is gradually replaced by nannofossil or nannofossil-rich claystone that frequently grades into the same bed. The intensity of biogenic reworking does not change significantly in the lithologically different sediment: Zoophycos is very rare and Skolithos and Teichichnus occur locally. In a few cases increasing downward, the basal part $(2-3 \mathrm{~cm})$ of the beds is composed of unbioturbarted massive siltstone and/or silty sandstone; rare escape traces rising from the top of the underlying mottled sediment have been observed. The transition to the underlying subfacies is very gradual.

In Subfacies $792 \mathrm{III}_{\mathrm{A} 3}$ (Cores 126-792E-29R to -31R), the beds are generally $10-30 \mathrm{~cm}$ thick and frequently grade from nannofossilrich claystone to a relatively thinner basal part of claystone or siltstone. Correspondingly, the intensity of biogenic reworking rapidly decreases from evenly and highly bioturbated to poorly bioturbated or unbioturbated (Fig. 21). Downcore (Core 126-792E-31R) the thickness of the bioturbated intervals as well as the degree of intensity decreases; furthermore, a lam-scram pattern becomes more common. The deepest example of this facies is a mottled nannofossil chalk bed $20 \mathrm{~cm}$ thick. The inventory of biogenic structures is similar to that of Subfacies $792 \mathrm{III}_{\mathrm{A} 2}$; in addition, large composite burrows, postdating all the others, and halo burrows are common.

Facies $792 \mathrm{III}_{B}$

The beds are generally unbioturbated.

\section{Interpretation}

Facies $792 \mathrm{III}_{\mathrm{A}}$

The ichnofabric indicates generally stable sea-bottom conditions, caused by fallout sedimentation, tending to change gradually, low or very low rates of sedimentation, although punctuated by short minor 


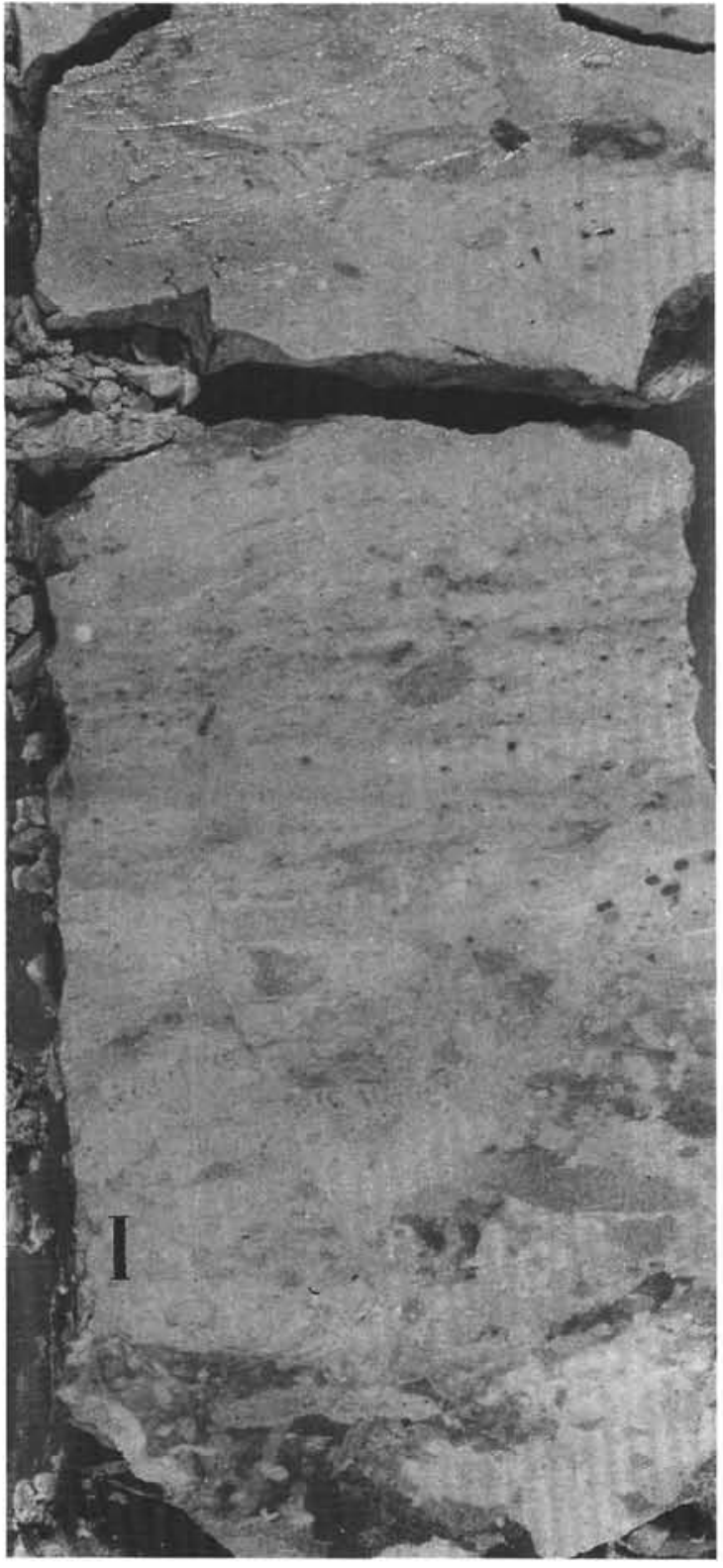

Figure 20. Core photograph, Site 792, Subfacies $792 \mathrm{III}_{\mathrm{A} 2}$. Complex ichnofabric in chalk grading downward to nannofossil claystone. Sample 126-792E28R-1, $47-60 \mathrm{~cm}$. Scale bar $=1 \mathrm{~cm}$.

events of sudden deposition, abundant buried nutrients, and well-oxygenated bottom water.

In Subfacies $792 \mathrm{III}_{\mathrm{Al}}$, vertical variations in the degree of trace fossil density followed by constant high values, as well as lithologic changes, document pulses in the rates of deposition and in the ratio of the different materials supplied. Rapidly deposited thin layers of volcaniclastic silt or silty sand tend to occur less frequently downcore, where finer grained, mostly pelagic material supplied by slow fallout dominate.

Subfacies $792 \mathrm{III}_{\mathrm{A} 2}$ represents the culmination of this trend, as indicated by its ichnofabric, typical of a chalk deposited at abyssal depths (Ekdale and Bromley, 1984). The fine abiogenic component gradually increases downward in the sequence, but the resulting nannofossil claystone does not affect significantly the quality of life conditions. Reduction in the trace fossil density or lack are very rare and related to the occasionally abrupt input of silty volcaniclastic material. The lack of climax trace fossils (Bromley, 1990), reflecting

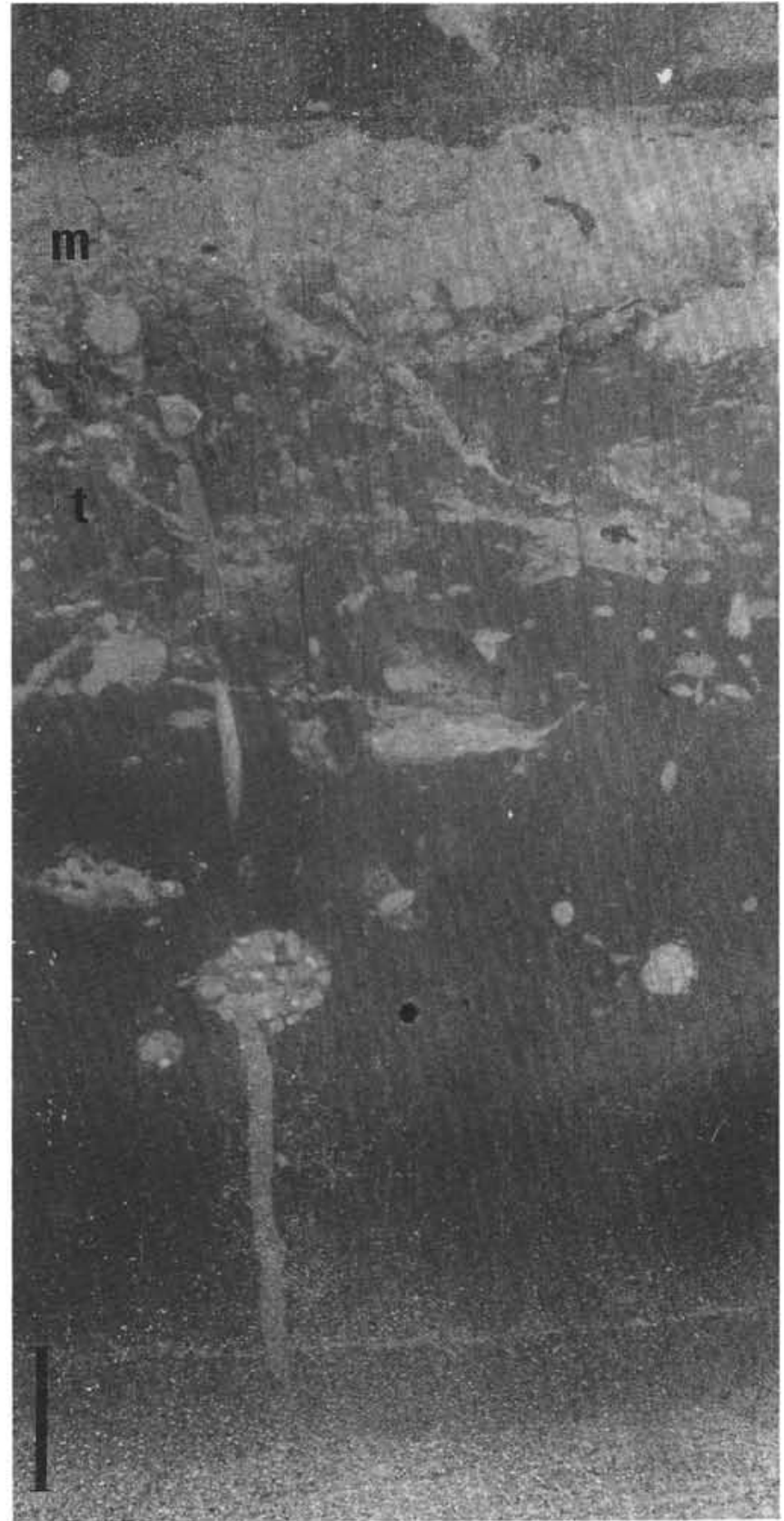

Figure 21. Core photograph, Site 792, Subfacies $792 \mathrm{III}_{\mathrm{A} 3}$. Characteristic ichnofabric of Subfacies $792 \mathrm{III}_{\mathrm{A} 3}$. Mixed (m) and transitional (t) layers are preserved. Turbidite bed grading into a whitish hemipelagic horizon. Sample 126-792E-31R-1, $89-99 \mathrm{~cm}$. Scale bar $=1 \mathrm{~cm}$.

long-term occupation or highly specialized feeding behaviors, is mainly the result of the final reworking of sediment by deeply burrowing organisms during the slow upward shifting of the tiers.

Numerous minor events of turbidite sedimentation are recorded in Subfacies $792 \mathrm{III}_{\mathrm{A} 3}$ by the characteristic lam-scram sequences. However, these events must have represented the abrupt and short-term input of siliciclastic material in an otherwise stable habitat, as is suggested by the thinness of unbioturbated parts grading into the bioturbated intervals, as well as by the cross-cutting relations of the multigenerations of burrows, possibly belonging to successional categories. A frozen tiered distribution of trace fossils was occasionally preserved by volcanogenic killer events. Downcore (from Cores 
126-792E-30R to -31R), the episodes of turbidite deposition increase in frequency.

On the whole, the ichnofabrics of Unit III are suggestive of a deep-sea setting characterized by slow to very slow hemipelagic deposition; minor turbidites occur in Subfacies $792 \mathrm{III}_{\mathrm{A} 1}$ but are more frequent in Subfacies $792 \mathrm{III}_{\mathrm{A} 3}$ where they also increase downcore. Periods of pelagic supply without significant volcanogenic input are recorded by the thick mottled nannofossil chalk intervals of Subfacies $792 \mathrm{III}_{\mathrm{A} 2}$.

\section{Facies $792 I I I_{B}$}

Sedimentary features in Facies $792 \mathrm{III}_{\mathrm{B}}$ suggest that these beds were deposited by low-concentration turbidite currents.

\section{Unit IV}

\section{Description}

Unit IV (429.3-783.4 mbsf; early Oligocene) is dominated by graded sandstone and siltstone turbidites interbedded with muddy intervals (see Hiscott et al., this volume). Beds of a sandy pebblegranule conglomerate are present in the middle and lower parts of the unit. Four facies were recognized.

\section{Facies $792 I V_{A}$}

Medium to very thick beds of conglomerate that can be ungraded, inverse to normally graded, or graded-stratified compose Facies $792 \mathrm{IV}_{\mathrm{A}}$. The conglomerate, which often passes upward into sandstone, is generally structureless, except for local concentrations of muddy intraclasts.

\section{Facies $792 I V_{B}$}

Facies $792 \mathrm{IV}_{\mathrm{B}}$ is made up of very thick sandstone, granule sandstone, and pebbly sandstone beds. Some beds have erosional bases and basal conglomeratic parts. Some are normally graded with tractional structures in their upper parts. Other beds are characterized by poor sorting and poorly developed clast fabric. One bed contains dish structures and fluid-escape pillars.

\section{Facies $792 I V_{C}$}

Very thin to thick graded siltstone and sandstone beds, normally showing Bouma (1962) sequences comprise Facies 792 IV $_{\mathrm{C}}$.

\section{Facies $792 I V_{D}$}

Mudstone beds generally occur between the coarse-grained units of Facies $792 \mathrm{IV}_{\mathrm{D}}$. They are only locally finely laminated; otherwise, they are commonly massive.

\section{Trace Fossil Assemblages}

Facies $792 I V_{A}$ and $792 I V_{B}$

The beds are unbioturbated in Facies $792 \mathrm{IV}_{\mathrm{A}}$ and $792 \mathrm{IV}_{\mathrm{B}}$.

\section{Facies $792 I V_{C}$}

Beds are generally unbioturbated in Facies $792 \mathrm{IV}_{\mathrm{C}}$. Only locally are burrows present in the upper part of the beds.

\section{Facies $792 I V_{D}$}

Vertical variations from rare scattered burrows to a totally bioturbated ichnofabric are typical of Facies $792 \mathrm{IV}_{\mathrm{D}}$. The thickness of the reworked intervals is variable, being generally limited to clayey or muddy beds or to the finer grained part of graded beds. In some cases of stacked thin bioturbated beds (Fig. 22), discrete trace fossils can be piped in the subjacent bed, but a biohomogenization rarely occurs. Downcore the episodes of bioturbation are rarefied; the thickness of each reworked horizon, as well as the degree of density reduced. The trace fossil assemblage is composed of numerous different generations of burrows attributed to the following ichnotaxa: different-sized Planolites and Chondrites, rarely co-occurring in composite burrows: subordinate Taenidium, Zoophycos, Teichichnus, and Skolithos; and extremely rare Thalassinoides. The values of ichnodiversity are normally medium to high, but they are not quantifiable in some vague burrow horizons lacking discrete structures. Tiered profiles, including mixed layers, are not rarely preserved.

\section{Interpretation}

Facies $792 I_{A}$

The graded to graded-stratified conglomerates were deposited by high-concentration turbidite currents. The structureless beds, characterized by poor fabric, poor grading, and large mudstone intraclasts well above the base of the beds, are interpreted as debris-flow deposits (Hiscott et al., this volume).

\section{Facies $792 I V_{B}$ and $792 I V_{C}$}

Sediments in Facies $792 \mathrm{IV}_{\mathrm{B}}$ and $792 \mathrm{IV}_{\mathrm{C}}$ were deposited by turbidite currents of both high and low concentration (Hiscott et al., this volume).

\section{Facies $792 I V_{D}$}

The pattern of trace fossil distribution in Facies $792 \mathrm{IV}_{\mathrm{D}}$ is characteristic of settings subjected to abrupt increase in the rate of sedimentation, caused in this case by turbidite deposition. Periods of slow accretion of the seafloor by hemipelagic input producing an organicrich stable substrate, in well-oxygenated bottom conditions, favored the establishment of infaunal communities recorded by the highly bioturbated or mottled ichnofabrics. These hemipelagic intervals, quite abundant in the upper part of the unit, gradually decrease downcore. The frequency of turbidite currents as well as the grain size of the sediments were the main factors that controlled the colonization of the bottom by benthic organisms and inhibited their development downward in the sequence. However, we have not excluded, in some cases, the possibility that the lack of bioturbation can be secondarily produced by erosive processes.

\section{Unit V}

\section{Description}

Unit V (783.4-804 mbsf; early Oligocene) comprises altered volcanic pebble-granule conglomerate and sandstone. Claystone and siltstone are present as clasts in the sandstone and in a brecciated mixture with volcanic rock. The severe alteration did not allow recognition of the possible presence of bioturbation. Possibly, the protolith of this material was a sedimentary rock of similar lithology to the sandstone and conglomerate in the lower part of Unit IV (Taylor, Fujioka, et al., 1990).

\section{CONCLUSIONS}

Sites 790 and 791, located in the Sumisu Rift, have undergone differential subsidence, resulting in a thickening of the basin fill toward the eastern margin of the half-graben and the volcanic arc. The eastward thickening has been significant, the sedimentary section at Site 791 being three times thicker than the time-equivalent section at Site 790. A substantial part of the basin infill is represented by fine-grained sediments containing up to $40 \%$ of biogenic sediment and deposited at high sedimentation rates (about $90 \mathrm{~m} / \mathrm{m}$.y. at Site 790 


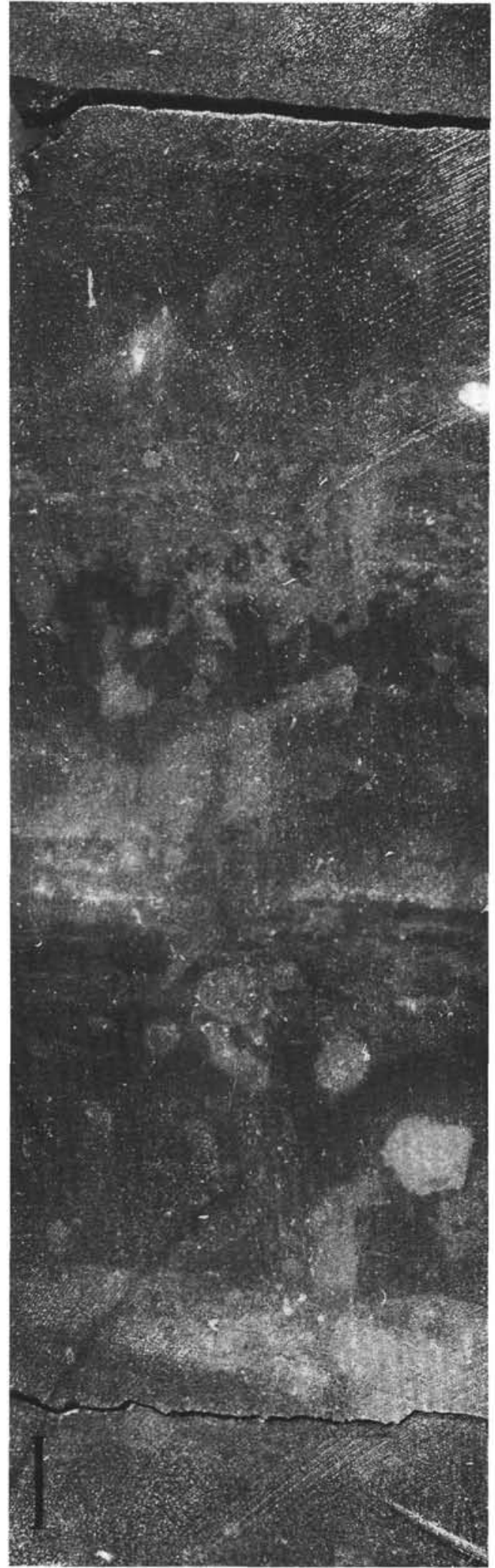

Figure 22. Core photograph, Site 792, Facies $792 \mathrm{IV}_{\mathrm{D}}$. Thin, stacked bioturbated beds; some trace fossils are piped into the underlying beds. Sample 126-792E-37-1, 20-37 cm. Scale bar $=1 \mathrm{~cm}$. to $345 \mathrm{~m} / \mathrm{m} . \mathrm{y}$. at Site 791 ) in a low-energy, bathyal ( 1500 to $>2000 \mathrm{~m}$ ) setting. The rapid sedimentation of volcaniclastic ash and clay implies a constant supply of fine-grained material to the basin. The fact that this material is not draped across the basin and dramatically thickens in the areas with the highest subsidence rates must imply that the bulk of the fine-grained sediments were emplaced by density currents flowing from the bathymetric highs into the Sumisu Rift, as well as settling from the overlying water column and redistribution by weak bottom currents.

This interpretation, suggested in Taylor, Fujioka, et al. (1990), was not supported by independent sedimentological data. On the contrary, the massive fine-grained sediments of Unit II were described as severely bioturbated throughout their thickness, with no evidence of mass-flow deposition. The detailed analysis of biogenic structures reported in this paper shows how most of the fine-grained sediments at Sites 790 and 791 were emplaced by sediment gravity flows, and only a minor part was provided by hemipelagic deposition. Different stress factors strongly limited or inhibited infaunal activities, so it is quite unlikely that the massive aspect of many thick muddy beds is the result of severe biogenic reworking as previously thought (Taylor, Fujioka, et al., 1990); on the contrary, the massive fabric is primary, being produced by rapid mass-flow deposition.

The ichnofabric suggests that the sediments of the backarc basin were characterized by low oxygen content and poor availability of nutrients. Indeed, the inferred anaerobic or dysaerobic conditions within the sediment are in agreement with the low to medium oxygen content in the bottom water indicated by the benthic foraminifers. Furthermore, the high rate of volcaniclastic supply was considered to be the main factor controlling the low density of bioturbation.

At Site 788 trace fossils are quite scarce. They are lacking in the coarse-grained volcaniclastic deposits as well as in the sand or silt deposited at a rate compatible with organic activity but devoid of nutrients. Finer sediments occur mainly in Unit II where few bioturbated intervals are preserved. Notwithstanding their paucity, trace fossils have provided some paleoenvironmental information on the tectonic history of Site 788, difficult to reconstruct because of the poor recovery from Hole 788D. One of the unclear aspects of the tectonic evolution of Site 788 is when it started to be a bathymetric high. Ichnofabric characters seem favorable to the hypothesis suggested by Taylor, Fujioka, et al. (1990), based on the relative abundance of foraminifers with respect to nannofossils and on the presence of glauconite, that in the interval from 4.1 to $3.8 \mathrm{Ma}$, Site 788 was already a bathymetric high but with less relief and at a greater water depth than during accumulation of Subunit IA.

The trace fossil assemblage in Subunit IIA is somewhat different from the one characterizing the fine-grained basinal deposits of the backarc and forearc, which are typical of low-energy, deep-water depositional settings. The unique occurrence of Scolicia and Skolithos in these beds, as well as the fact that they are superimposed and then postdate an ichnofabric association typical of low-energy settings (Chondrites, Planolites, and Helminthopsis), indicates that the site was a low-energy setting that episodically was subjected to conditions of higher hydrodynamism, possibly produced by the flow of weak bottom currents. This created a favorable setting for glauconite to form and caused winnowing of nannofossils (Taylor, Fujioka, et al., 1990).

At Site 792 in the forearc basin, the biogenic structures are more widespread than at other sites; furthermore, the values of burrowing intensity and ichnodiversity are usually higher. In general, the trace fossil assemblages suggest constantly well-oxygenated bottom waters in agreement with foraminifer data. Long periods of hemipelagic deposition at a relatively high rate, punctuated by minor events of mass-flow sedimentation, are suggested by the ichnofabrics for the bulk of Units I and II. Changes in trace fossil density once again depended on fluctuations in the rate of volcaniclastic input; excessive 
supply could produce food starvation into the substrate, limiting or inhibiting the infaunal activities. The events of mass-flow deposition, as well as the quantity and the grain size of the volcaniclastic material decrease toward the base of Unit II. This trend culminates in the pelagic-dominated sediments of Unit III, Subfacies $\mathrm{III}_{\mathrm{A} 2}$.

Conditions favorable to a high biogenic reworking (i.e., very low and gradual accretion of the seafloor and a nutrient-rich bottom) lasted during the formation of Subfacies $\mathrm{II}_{\mathrm{A} 3}$, characterized by hemipelagic sedimentation, although downcore some turbidite beds occur. Deposition from turbidite currents became increasingly important in Unit IV, as suggested by the burrow distribution; the frequency of mass-flow deposition also increases downward in the sequence where the combined actions of these main negative factors resulted in a primary lack of trace fossils.

Trace fossils, as well as the petrography and morphoscopy of volcanic clasts, have substantially improved our understanding of the depositional processes responsible for sedimentation of the apparently massive sandy mudstones and muddy sandstones of Unit II at Site 792. Taylor, Fujioka, et al. (1990) suggested that poor sorting and the massive aspect were secondary, being the result of bioturbative mixing of hemipelagic mud with thin beds of volcanic grains. This study indicates that biogenic reworking is only partly responsible for the massive aspect of the sediment. Most of the sediments of Unit II were emplaced by fallout of hemipelagic mud together with pyroclastic grains of different composition and size, supplied to the sea by the fall of pyroclastic ejecta from subaerial explosions of arc volcanoes.

\section{ACKNOWLEDGMENTS}

We thank R. Bromley, K. Fujioka, R. Hiscott, and an anonymous referee for their helpful review of the manuscript. We gratefully acknowledge B. Bryant for the availability of the X-ray machine and for his kind assistance in the technical work.

\section{REFERENCES}

Bouma, A. H., 1962. Sedimentology of Some Flysch Deposits: Amsterdam (Elsevier).

Bromley, R. G., 1990. Trace Fossils: Biology and Taphonomy: London (Unwin Hyman).

Bromley, R. G., and Ekdale, A. A., 1984. Chondrites: a trace fossil indicator of anoxia in sediments. Science, 224:872-874.

Droser, M. L., and Bottjer, D. J., 1986. A semiquantitative field classification of ichnofabric. J. Sediment. Petrol., 56:558-559.

Ekdale, A. A., and Bromley, R. G., 1984. Comparative ichnology of shelf-sea and deep-sea chalk. J. Paleontol., 58:322-332.

Ekdale, A. A., Bromley, R. G., and Pemberton, S. G., 1984. Ichnology: The Use of Trace Fossils in Sedimentology and Stratigraphy. SEPM Short Course, No. 15.

Frey, R. W., and Seilacher, A., 1980. Uniformity in marine invertebrate ichnology. Lethaia, 13:183-207.

Howard, J. D., 1978. Sedimentology and trace fossils. In Basan, P. B. (Ed.), Trace Fossil Concepts. SEPM Short Course Notes, 5:13-47.

Savrda, C. E., and Bottjer, D. J., 1989. Trace fossil model for reconstructing oxygenation histories of ancient marine bottom waters: application to Upper Cretaceous Niobrara Formation, Colorado. Palaeogeogr., Palaeo. climatol., Palaeoecol., 74:49-74.

Taylor, B., Fujioka, K., et al., 1990. Proc. ODP, Init. Repts., 26: College Station, TX (Ocean Drilling Program).

Wetzel, A., 1987. Ichnofabrics in Eocene to Maestrichtian sediments from Deep Sea Drilling Project Site 605, off the New Jersey coast. In van Hinte, J. E., Wise, S. W., Jr., et al., Init. Repts. DSDP, 93: Washington (U.S. Govt. Printing Office), 825-835.

Date of initial receipt: 10 January 1991

Date of acceptance: 11 September 1991

Ms 126B-129 